\title{
La televisión local digital terrestre en Andalucía y el cese de emisiones en analógico
}

\author{
Juan Francisco Sánchez Barrilao \\ Prof. Titular de Universidad de Derecho Constitucional \\ Universidad de Granada
}

SUMARIO:I.- INTRODUCCIÓN: LA TELEVISIÓN LOCAL CON OCASIÓN DEL APAGÓN ANALÓGICO. II.- MARCO JURÍDICO DE LA ACTIVIDAD TELEVISIVA: II.A.- TELEVISIÓN Y CONSTITUCIÓN. II.B.- RÉGIMEN LEGAL Y LIBERALIZACIÓN DE LA TELEVISIÓN. II.C.- TELEVISIÓN YESTADO AUTONÓMICO. III.- LA LEY DE TELEVISIÓN LOCAL TERRESTRE: III.A.- LA LEY 41/ 1995 DE TELEVISIÓN LOCAL POR ONDAS TERRESTRES. III.B.- EL PROYECTO LIBERALIZADOR DE 1997 DE REFORMA DE LA LEY 41/ 1995. III.C.- LA TELEVISIÓN LOCAL TERRESTRE DIGITAL. III.D.- LA TELEVISIÓN DE PROXIMIDAD SIN ÁNIMO DE LUCRO. III.E.PARADOJAS EN TORNO AL RÉGIMEN LEGAL DE LA TELEVISIÓN LOCAL TERRESTRE. IV.- LA TELEVISIÓN LOCAL EN ANDALUCÍA:IV.A.- EL RÉGIMEN TRANSITORIO. IV.B.- EL DECRETO 1/2006 POR EL QUE SE REGULA EL RÉGIMEN JURÍDICO DE LASTELEVISIONES LOCALES POR ONDAS TERRESTRES EN ANDALUCÍA. IV.C.- EL NUEVO MARCO ESTATUTARIO. IV. D.- EL CESE EFECTIVO EN ANDALUCÍA DE EMISIONES TELEVISVAS LOCALES EN ANALÓGICO. V.- EPÍLOGO: EL PROYECTO DE LEY GENERAL DE LA COMUNICACIÓN AUDIOVISUAL: V.A-. APROXIMACIÓN CRÍTICA AL NUEVO RÉGIMEN LEGAL DE LA TELEVISIÓN QUE SUPONE EL PROYECTO DE LEY AUDIOVISUAL. V.B.- LA TELEVISIÓN LOCAL EN LA LEYGENERAL DE COMUNICACIÓN AUDIOVISUAL

Resumen: El presente trabajo tiene por objeto una aproximación crítica al marco normativo regulador de la actividad televisiva local a la vista, fundamentalmente, del rol que dichas televisiones ejercen y de los derechos y libertades en juego; y ello, a su vez, desde una perspectiva esencialmente diacrónica, a fin de procurar una adecuada apreciación de la situación jurídica alcanzada al respecto de la televisión local en España, en general, y en Andalucía, en especial, con ocasión del llamado "apagón analógico" en 2010. A este fin se analiza el marco constitucional y legal de la televisión, con particular atención al proceso de liberalización de la misma y al Estado autonómico; de manera 
más concreta, luego, el régimen jurídico de la televisión local y su evolución legal a nivel estatal, y el desarrollo normativo de la televisión local, ahora, en la Comunidad Autónoma de Andalucía; y por fin, el cese efectivo en Andalucía de emisiones televisivas locales en analógico. Para terminar, se presenta un análisis de urgencia del todavía proyecto de Ley General de la Comunicación Audiovisual,, así como de su incidencia en la televisión local.

Palabras clave: Televisión local, televisión digital, televisión privada, Estado autonómico, régimen jurídico de la televisión.

Abstract: This paper wants to give a critical assesment to the law of local television, under the light of the roll played by this television and the liberties that are at stake. To this porpouse the paper takes an historical view, trying ton analyze the evolution of the legislation in Spain and Andalucia, and for all takes a look to the so called "analogical blackout" that will occur in 2010. In this context, the paper studies the constitutional and legal framework of local television, how this framework has been developed by the state and regional law, and finally tries to describe the legal consequences of the "analogical blackout". Also, thepaper analyzes the new Audiovisual law and its impact on local television.

Key words: Local television, digital television, private television, Federal State, television law.

\section{INTRODUCCIÓN: LA TELEVISIÓN LOCAL CON OCASIÓN DEL APAGÓN ANALÓGICO}

El apagón de la televisión analógica previsto en España para el tres de abril de $2010^{1}$, con toda la panoplia de reformas legales llevadas a cabo en pos

\footnotetext{
${ }^{1}$ Disp. adic. 1a RD 944/ 2005, de 29 de julio, y Acuerdo del Consejo de Ministros por el que se aprueba el Plan Nacional de transición a la televisión digital terrestre, de 7 de septiembre de 2007. A tales efectos, dicho Acuerdo contempla un calendario de transición que establece cuatro fases para el cese de las emisiones analógicas: la primera, y como programa piloto, el llevado a cabo en la Provincia de Soria y finalizado el 31 de diciembre de 2008; y las tres restantes, organizadas en torno a tres grupos distintos de proyectos, atendiendo al tamaño de la población incluida en cada proyecto y a la infraestructura que se precisa en cada caso para garantizar la cobertura proyectada (primer grupo, aquéllos que cubren una población de menos de 500.000 habitantes, cuentan con un alto porcentaje de cobertura de TDT y necesitan un número reducido de reemisores para alcanzar una cobertura similar a la analógica, completarán la transición el 30 de junio
} 
de la progresiva implantación de la televisión digital, resulta una magnífica oportunidad para revisitar el régimen jurídico de la actividad televisiva; y ello, especialmente, respecto a la televisión local, dada la previsión legal de cierre de numerosas cadenas locales aún hoy existentes (al momento de escribir estas páginas) ${ }^{2}$. Y es que tal apagón y cierre, adelantamos, no se presenta carente de problemas: de un lado, por cuanto que no pocas de las televisiones locales analógicas a cesar en su actividad cuentan, sin embargo, con un importante arraigo en su comunidad; de otro, en razón al carácter de cercanía que a la televisión local se le reconoce, y así el que tal actividad suponga una particular manifestación de las libertades de expresión e información en el ámbito televisivo; y por último, en atención a cómo un buen número de dichas tele-

de 2009; el segundo grupo de proyectos, aquéllos que tienen una población de entre 500.000 y 700.000 habitantes, completarán la transición el 30 de diciembre de 2009; y tercer grupo, aquéllos que cubren una población de más de 700.000 habitantes y/ o que necesitan de la instalación de un número importante de centros para alcanzar una cobertura similar a la analógica, completarán la transición el 3 de abril de 2010).

\footnotetext{
2 Decimos "revisitar", por cuanto que ya en el pasado tuvimos la oportunidad de analizar la televisión local: "El derecho fundamental a la actividad televisiva" (I) y (II), Revista Jurídica de Andalucía, respectivamente núms. 18 y 19, 1996, pp. 35 y ss. y 591 y ss.; y muy especialmente "La liberalización de la televisión local", Revista de la Facultad de Derecho de la Universidad de Granada, núm. 1, 1998, pp. 119 y ss. En esta ocasión, la invitación de los compañeros Rafael BARRANCO VELA y Francisco Miguel BOMBILLAR SÁENZ (del Departamento de Derecho Administrativo de la U niversidad de Granada) a participar en el Seminario "Aspectos legales de la comunicación audiovisual", en relación a "La televisión local ante el apagón analógico" (junto a Matilde Santiago Cossi, Directora General de Comunicación Social -Consejería de Presidencia, Junta de Andalucíay a José Luis RAMÍREZ DOMENECH, Director de Radio Granada-Cadena SER y Granada Televisión), y celebrado en la Facultad de Comunicación y Documentación de la Universidad de Granada ( 15 de enero de 2009), nos obligó a volver a tales trabajos y analizar el desarrollo normativo ulterior; estas páginas son así parte de las reflexiones que alcanzamos en dicha intervención. Pero una nueva invitación de dichos compañeros (a la que se suma ahora la de Leonardo SÁNCHEZ MESA) me ha llevado otra vez (y estando ya ultimadas estas páginas y entregadas a imprenta) a revisitar el marco legal de la televisión a la vista del Proyecto de Ley General de la Comunicación Audiovisual, en adelante PLGCA (aprobado en el Congreso de los Diputados, Comisión Constitucional, a fecha de 7 de enero de 2010, y en trámite de traslado al Senado al momento de redactar esta nota), si bien centrándome al respecto al final del texto por razones de sistematicidad y lógica planificación en relación al trabajo ya entregado a la Revista; fue nuevamente una mesa redonda, en torno ahora a dicho Proyecto de Ley (en este caso, junto a Miguel AZPITARTE SÁNCHEZ, compañero de Departamento de Derecho Constitucional de la Universidad de Granada), y celebrada el 14 de enero de 2010 en la referida Facultad de Comunicación y Documentación). Por último, también quisiéramos aprovechar esta nota para mostrar nuestro agradecimiento a Enrique GUILLÉN LÓPEZ, compañero asimismo del Departamento de Constitucional, por sus comentarios y sugerencias.
} 
visiones locales han sido toleradas por los propios poderes públicos, a sabiendas de la situación jurídica irregular en que se encontraban las mismas 3 .

Es de este modo que dediquemos las siguientes páginas a una aproximación crítica al marco normativo regulador de la actividad televisiva local a la vista, fundamentalmente, del rol que dichas televisiones ejercen y de los derechos y libertades en juego; y ello, a su vez, desde una perspectiva esencialmente diacrónica, pues sólo desde tal acercamiento cabe alcanzar una adecuada apreciación de la situación jurídica alcanzada al respecto de la televisión local en España, en general, y en Andalucía, en especial.

\section{MARCO JURÍDICO DE LA ACTIVIDAD TELEVISIVA}

\section{II.A.- TELEVISIÓN Y CONSTITUCIÓN}

Lo primero que llama la atención cuando nos aproximamosal marco normativo de la televisión en España es la disparidad de regímenes jurídicos existentes en relación a ésta, según cuál sea su modalidad (por ondas terrestres, por satélite o por cable; analógica o digital; nacional, autonómica o local; y su vez en "abierto", o en la opción "de pago" o "condicional") 4; la razón de ello se encuentra en cómo sus diversas modalidades técnicas presentan características tales que dificultan su homogeneidad jurídica. Sin embargo cabría postular, al margen de tal falta homogeneidad, cierta unidad y coherencia básica a tenor de los derechos y libertades que al respecto se ven afectados (arts. 20.1.a y d, y $38 \mathrm{CE}$ ), y desde esta perspectiva que nos preguntemos: si existe un

${ }^{3}$ Con carácter general, vid. Ángel BADILLO y María de los Ángeles M ORENO, "La liberalización del audiovisual local: apunte sobre el caso de Castilla y León", en www.usc.es/ xorna/ SECCOM/ textos/ A_B2.pdf (21/ 03/ 2009), 10 pp. Y ello, todavía más, en relación al referido PLGCA.

\footnotetext{
${ }^{4}$ Para un primer acercamiento a diversas modalidades de televisión (si bien antes de la aparición de la TDT), vid. José Carlos LAGUNA DE PAZ, Régimen jurídico de la televisión privada, Marcial Pons, Madrid, 1994, pp. 21 y ss. No obstante, se ha de advertir el anuncio por el Gobierno de su intención de impulsar de una regulación general e integral de lo audiovisual (25/6/2009); anuncio que, al tiempo, adquiere carácter imperativo a la vista de la disp. adic. 6 a de la L 8/ 2009, de 28 de agosto, de financiación de la Corporación de Radio y Televisión Española, conforme a la cual "el Gobierno deberá remitir, en el plazo de un mes, el Proyecto de Ley General Audiovisual, que deberá definir un modelo completo de televisión pública". Con él, obviamente, nos estamos refiriendo al citado PLGCA, en trámite ya de aprobación en el Senado, y respecto del cual nos centramos al final de estas páginas da la absoluta transformación que del régimen legal de la televisión éste supone.
} 
derecho a la actividad televisiva y, en su caso, en qué consista; y a la postre, cómo incida éste en el régimen jurídico de la televisión, en general, y de la local, en particular.

Si por actividad televisiva se entiende transmisión y/ o recepción a distancia de sonidos e imágenes en movimiento, cabe deducir en ésta una doble dimensión: una activa, transmitir, y otra pasiva, recibir. Los principales intentos por reconocer esta actividad como derecho han partido fundamentalmente desde las categorías de libertad de antena y televisión privada, al amparo de las libertades de comunicación y empresa contenidas, respectivamente, en los artículos 20.1 (a y d) y 38 de la Constitución; en estos dos casos la televisión es considerada esencialmente desde la posición activa de un sujeto emisor televisivo, en tanto que titular de un derecho ante los poderes públicos a expresarse e informar por medio de la transmisión de sonidos e imágenes en movimiento. A su vez, es posible distinguir entre ambas categorías en razón al distinto fundamento que en verdad se encuentra en ellas: así, por televisión privada comprendemos una forma de ocupación y organización empresarial privada dirigida a la obtención de beneficios mediante la actividad tel evisiva ( art. $38 \mathrm{CE}$ ) ; mientras que, por libertad de antena, la facultad de creación de medios de comunicación televisivos y de emisión a través de ellos, para lograr una libre expresión e información (art. 20.1.a y d CE) ${ }^{5}$. Sin embargo, el artículo

\footnotetext{
${ }^{5}$ Dos son así las notas que identifican la televisión privada: la primera es su carácter mercantil y privado, en tanto que la propiedad, la organización de los medios materiales y personales, y la toma de decisión en materia de programación corresponden a un empresario privado; y la segunda nota es su finalidad esencialmente lucrativa, en cuanto que ordenada a la captación de la mayor audiencia posible como medio de obtención de ingresos publicitarios. Concebida de este modo la televisión privada, su régimen constitucional vendría determinado principalmente por el art. 38 CE (libertad de empresa). Mientras, en cuanto a la libertad de antena cabe distinguirse de la televisión privada en razón a la preponderancia que en la primera hay de las libertades a la comunicación contempladas en el art. 20.1.a y d CE, frente al protagonismo de la libertad de empresa en la segunda (art. $38 \mathrm{CE}$ ). Pero incluso cabe sostener la no necesaria conexión entre libertad de antena y libertad de empresa, pues: una cosa es que, por los altos costes requeridos para el ejercicio de la actividad televisiva, la empresa aparezca como forma oportuna de organización para cubrir dichos costes; y otra, que necesariamente dicha actividad deba desarrollarse mediante una organización mercantil. De otra parte, la hipótesis de considerar la libertad de antena como un derecho fundamental nos lleva también a tener en cuenta la historicidad de los derechos fundamentales, en general, y de la libertad de imprenta y prensa, en particular. Ha sido la evolución de las circunstancias históricas lo que ha determinado en cada momento el alcance de las libertades en razón a sus fines vitales y a los obstáculos que las venían impidiendo. En este sentido, la represión que sobre la imprenta se realizó durante el Antiguo Régimen, dio lugar a que pronto ésta fuera reconocida como libertad en las primeras declaraciones históricas de derechos;
} 
128.2 de la Constitución permitió al legislador la declaración de la televisión como servicio público de titularidad estatal, en cuanto que actividad esencial para la comunidad (por todas, STC 12/ 1982). Ello, a la postre, ha dificultado la comprensión de la televisión privada y de la libertad de antena como plenos derechos fundamentales, ya que la publicatio de la actividad televisiva conllevaba sostener como único titular de derechos a emitir por este medio al poder público (en particular, el Estado), sin perjuicio de que su gestión pudiera ser encomendada a particulares mediante concesión administrativa ${ }^{6}$; y así, al hilo de ello, el entendimiento de un derecho de acceso a los medios televisivos en régimen de igualdad, y en tanto que instrumental de la más amplia y superior libertad de expresión e información (STC 329/2005).

En conexión con la anterior dimensión positiva se encuentra asimismo el artículo 20.3 de la Constitución, según el cual la ley "garantizará el acceso" de "los grupos sociales y políticos significativos" a los medios de comunicación públicos, "respetando el pluralismo de la sociedad y de las diversas lenguas de

\begin{abstract}
y las limitaciones técnicas en aquel momento, a la equiparación entre derechos a los medios de comunicación y libertad de prensa. Desde esta perspectiva se comprende cómo la televisión se vendría a sumar al tradicional cuadro de medios de comunicación y al reconocimiento implícito que la CE de 1978 hace de la libertad de imprenta y prensa en su art. 20.1.a y d, cuando habla de cualquier "otro medio de reproducción" o "medio de difusión". Respecto a la televisión privada y la libertad de antena, cfr.: en cuanto a la primera, Santiago VARELA, "Constitución, monopolio público y televisión", Revista de Derecho Político, núm. 6, 1980, pp. 40 a 48; y en cuanto a la segunda, Luis JIMENA QUESADA, "La libertad de creación de medios de comunicación en la jurisprudencia constitucional: el caso particular de la televisión por cable y el video comunitario", Re vista General del Derecho, núms. 601-602, 1994, pp. 10902 a 10904.
\end{abstract}

${ }^{6}$ Sobre la incompatibilidad en abstracto entre la declaración de la actividad televisiva como servicio público y el reconocimiento de auténticos derechos subjetivos a esta actividad, cfr. Francisco J. BASTIDA, La libertad de antena, Ariel Barcelona, 1990, Capítulos XIV y XV. De este parecer vid., también: Gaspar ARIÑ O, EI proyecto de ley sobretelevisión privada, IEE, Madrid, 1987, pp. 78 y ss.; Juan José SO LOZÁBAL ECHAVARRÍA, "Ordenación jurídica de la televisión en España", Cuadernos de la Cátedra FadriqueFurió Ceriol, núm. 5, 1993, pp. 37 y 38; y Fernando SANTAO LALLA LÓ PEZ, "Televisión por cable y control de omisiones del legislador (En torno a la STC 31/ 1994, de 31 de enero). Epílogo sobre la televisión privada (STC 127/ 1994)", Revista Española de Derecho Constitucional, núm. 41, 1994, pp. 179, 183 y 184. Por otra parte, a favor del servicio público y de la concesión como título habilitante para el ejercicio de la actividad televisiva por los ciudadanos, cfr. Enrique GARCíA LLOVET, El régimen jurídico de la televisión, Marcial Pons, Madrid, 1991, en especial pp. 323 a 326. Asimismo vid. Ios trabajos de Carmen CHINCHILLA MARÍN : La radiotelevisión como servicio público esen cial, Tecnos, Madrid, 1988; y “El servicio público, ¿una amenaza o una garantía para los derechos fundamentales?. Reflexiones en el caso de la televisión", en AAVV H omenaje al Profesor Eduardo García de Enterría (II), Sebastián Martín Retortillo (coord.), Cívitas, Madrid, 1991. 
España"7. La Constitución vendría de este modo a establecer un derecho de acceso de los grupos sociales y políticos, si bien dejando un amplio margen al legislador a tales efectos (STC 63/ 1987) ${ }^{8}$. Ahora bien, se ha de remarcar que dicho acceso se refiere en relación a medios televisivos de titularidad pública existentes, y no respecto a un acceso directo a la actividad televisiva en favor de los particulares, lo que a la postre resulta totalmente compatible con la publicatio de la televisión más arriba señalada.

Desde la dimensión pasiva de la televisión ahora, ya partir de la conexión existente entre pluralismo externo y derecho a la información (art. 20.1.d CE) , la actividad televisiva no giraría ya en torno al emisor, directamente, sino al sujeto receptor o televidente, en tanto que titular de un derecho a recibir información de una pluralidad de entes televisivos. En este sentido, los poderes públicos no pueden garantizar al ciudadano de modo absoluto la veracidad y pluralidad de la información que éste recibe de los medios de comunicación; ni tampoco, incluso, la propia existencia de dicha información, pues ello depende de que sus conciudadanos decidan ejercer las libertades de expresión e información. Pero lo que aquéllos sí pueden, en cambio, es garantizar la existencia de un marco jurídico tal que permita el ejercicio de estas libertades y una pluralidad externa de medios de comunicación a este fin, y con ello "el derecho fundamental de los ciudadanos en cuanto espectadores a recibir una información libre y pluralista a través de la televisión" (STC 127/ 1994). Desde esta concepción los inconvenientes más arriba señalados sobre la publicatio no parecen ser tales, a la vista de la posibilidad de que existan varios emisores públicos y/ o privados (en este caso, como gestores indirectos del servicio público) ${ }^{9}$.

\footnotetext{
${ }^{7}$ Con carácter general, vid. Enrique LINDE PANIAGUA, José María VIDAL BELTRÁN y Sara MEDINA GONZÁLEZ, Derecho audiovisual, 3ạ ed., Colex, Madrid, 2009, pp. 156 y ss.

8 Por ejemplo, José Ramón PARADA VÁZQUEZ y Mariano BACIGALUPO SAGGESE, "Artículo 20.3. El control parlamentario de los medios de comunicación del Estado", en AAVV Comentarios a la Constitución española de 1978 (II), Oscar Alzaga Villaamil (ed.), Cortes Generales-EDERSA, Madrid, 1997, pp. 555 y ss.

${ }^{9} \mathrm{El}$ art. 20.1.d CE, casi de modo literal, viene a garantizar dos derechos distintos respecto a la libre información: el de comunicarla y el de recibirla; este último consiste en el derecho a recibir libremente información veraz por cualquier medio de difusión, y posee carácter mixto en cuanto necesario para el desarrollo democrático y la libre personalidad de los individuos. Entendido de esta forma el derecho a recibir información, su identificación con el pluralismo externo procede de considerar que sólo es posible este derecho cuando el ciudadano puede recibir distintas opiniones; así, un paso más en relación a la televisión sería estimar el derecho a recibir información
} 
Por último, también desde el pluralismo externo, pero ahora en conexión con la libertad de prestación de servicios y de establecimiento en la Unión Europea (art. 18.1 TCE), cabe la posibilidad de plantear la existencia de derechos a la actividad televisiva de nuevo desde su vertiente activa. Sin embargo, y a la postre, desde el mercado único europeo de la televisión creado a partir de la aplicación de las libertades comunitarias al sector televisivo (arts. 49 y 43 TCE) y la libre competencia (arts. 81 a 89 TCE), tampoco se encuentran elementos suficientes para desgranar un derecho a tal actividad en cuan-

como fundamento y exigencia de un modelo organizativo de la actividad televisiva basado en la pluralidad y concurrencia de medios y fuentes, y nunca en su concentración, sea pública o privada. Desde esta perspectiva el receptor de la información televisiva no queda ya limitado a una posición meramente pasiva en la relación que se establece en la comunicación por televisión; al contrario, éste asume un papel activo al poder ahora elegir u optar entre una diversidad de mediose información simultanea, lo que además le permite ser él, incluso, quien elabore su propia información a partir de las distintas recibidas (el fenómeno del zapping ilustra adecuadamente esta nueva forma de entender el derecho a la información televisiva: el ciudadano, mediante sucesivos cambios de canales en brevísimos espacios de tiempo, puede simultanear la visión de un mismo espacio o programa - noticiario- en diferentes emisoras de televisión; de este modo, el televidente puede, también, seleccionar el emisor, la información, e incluso partes de éstas según su origen y a cómo hayan sido tratadas por los distintos medios; el último paso sería, así, la facultad del receptor de crear su propia información con arreglo a la previamente seleccionada). A estos efectos, el derecho a recibir información televisiva plural pasa en un Estado como el nuestro (social y democrático de derecho), por una intervención positiva tendente a que se haga valer el pluralismo externo en la actividad televisiva frente a situaciones de concentración, privadas o públicas, de los medios televisivos. Cabe configurar así este derecho como un derecho a acciones positivas normativas, en virtud del cual los poderes públicos están obligados a normar en favor de la concurrencia entre dichos medios. No en vano, para el Tribunal Constitucional, "Ios derechos fundamentales no incluyen solamente derechos subjetivos de defensa de los individuos frente al Estado, y garantías institucionales, sino también deberes positivos por parte de éste" (STC 53/ 1985, de 11 de abril, FJ núm. 4). Consecuentemente, el poder público no sólo no puede limitar o impedir a los ciudadanos la recepción de información de distintas fuentes existentes, sino que además está obligado, en especial el legislador, a establecer un régimen jurídico tal en el que sea potencialmente posible la concurrencia de fuentes informativas; con ello el ciudadano podría recibir una información plural y, por tanto, más objetiva, bien optando por aquélla que considere más veraz, o bien deduciendo el mismo, de entre todas, la que estime más adecuada. Los poderes públicos no pueden garantizar al ciudadano de manera absoluta la pluralidad en la información, pero lo que sí pueden es no obstaculizarla; este derecho no garantiza un concreto marco jurídico en post de una determinada manera de reglamentar la pluralidad externa de los medios televisivos, pero sí protege, en cambio: de aquél que obligue o determine a la concentración de éstos, en todo caso; y del que reduzca el pluralismo posible a un número máximo de medios, siempre que ello no resulte suficientemente justificado conforme al mantenimiento de una mínima concurrencia. Cfr. Juan Francisco SÁNCHEZ BARRILAO, "EI derecho fundamental a la actividad televisiva (I )... cit., pp. 39 a 43, y 45 y 46. Singular mención requiere, de la doctrina cit. en tales páginas, el trabajo de Ignacio VILLAVERDE MENÉNDEZ, Los derechos del público, Tecnos, Madrid, 1995. 
to que ello únicamente garantiza la prohibición de abusos en la posición privilegiada en la que se encuentren medios tel evisivos nacionales (especialmente de los públicos) en relación a las emisiones procedentes de otros Estados miembros; se puede de este modo hablar de la exigencia comunitaria de un mercado televisivo a nivel europeo (Directiva 89/ 552 del Consejo, de 3 de octubre, a fin de lograr la libre circulación de los servicios de radiodifusión en el ámbito de la Unión Europea), mas no a escala nacional (regional o local), donde los poderes públicos pueden conservar una posición preferente y privilegiada en la televisión ${ }^{10}$.

Con todo, yen cuanto a la televisión en su modalidad local, de manera específica, cabe apreciar una particular imbricación cualitativa con los derechos fundamentales anteriormente señalados. Y esto, de un lado, por la mayor cercanía que se da entre emisores y receptores a nivel físico y de intereses (culturales, sociales, económicos y políticos); de otro, por los menores costes que la televisión local (en particular la analógica) supone (frente a los demás tipos televisivos), siendo así también más accesible para la ciudadanía; como, y en conexión con lo anterior, por el carácter tradicionalmente más espontánea y amateur de esta televisión (sin perjuicio de su progresiva profesionalización), lo que ha potenciado la intervención directa y personal de ciudadanos y colectivos. Consecuencia de lo anterior ha sido, precisamente, la progresiva proliferación de televisiones locales por todo el territorio nacional desde comienzos de la década de los ochenta del pasado Siglo (la más de las veces, eso sí, de muy reducido alcance territorial, dadas sus limitaciones técnicas) , a pesar de no encontrarse legalmente permitida hasta la segunda mitad de la década de los noventa ( según se viene a mostrar más adelante), y por tanto bajo la permanente amenaza de cierre de las mismas. Es de esta forma que la televisión local se nos presente, aunque como instrumental a las libertades de expresión e información, menos confinada tanto a las limitaciones técnicas y

\footnotetext{
${ }^{10} \mathrm{Cfr}$. Tomás de la QUADRA-SALCEDO, Liberalización de las telecomunicaciones, servicio pú blico y constitución económica europea, Centro de Estudios Constitucionales, Madrid, 1995, en especial pp. 91 y 100. También, sobre la creación del mercado único europeo televisivo y acerca de cómo la Sentencia Sacchi, de 30 de abril de 1974, del Tribunal de Justicia de la Comunidad, se acepta que los Estados substraigan la televisión al juego de la libre competencia, pero sólo en el sentido de retener su capacidad de emisión, vid. Santiago MUÑOZ MACHADO, Público y privado en el mercado europeo de la televisión, Cívitas, Madrid, 1993, pp. 18, 19, 41, y 43 y ss.; asimismo de interés, Mercedes CU RTO POLO, "La libertad de recepción y de retransmisión de emisiones de radiodifusión televisiva y su relación con la propiedad intelectual", en AAVV Comentarios a la Constitución Europea (III), Enrique Álvarez Conde y Vicente Garrido Mayol (dirs.), Tirant lo Blanch/ Consell Jurídic Consultiu de la Comunitat Valenciana, Valencia, 2004, pp. 189 y ss.
} 
económicas (por ser más accesible y motivadora para los particulares), como a la propia libertad de empresa, y por tanto, y a primera vista, menos condicionada por los condicionantes (valga la redundancia) técnicos, profesionales, económicos y políticos de la televisión nacional y regional; pero además, también, más cercana con el derecho a recibir información, por cuanto que más inserta y contextualizada en la comunidad en la que se desarrolla.

\section{II.B.- RÉGIMEN LEGAL Y LIBERALIZACIÓN DE LA TELEVISIÓN}

En 1978 la actividad televisiva estaba sometida en nuestro país a un férreo control público en forma de servicio público y en régimen de monopolio, todavía fundamentado en la Ley republicana del Servicio de Radiodifusión, de 26 de junio de 1934. Este régimen jurídico de la televisión continuó tras la entrada en vigor de la Constitución (al amparo del referido art. 128.2 CE), al ser revalidado por el legislador en 1980 con el Estatuto de Radiotelevisión (L 4/ 1980, de 10 de enero): el artículo 1.2 del Estatuto volvía a declarar la actividad televisiva como un servicio público esencial de titularidad estatal ${ }^{11}$. No obstante, el consenso político con que fuera aprobado el Estatuto de Radiotelevisión no se vio totalmente reflejado a nivel social, donde determinados grupos (como por ejemplo la sociedad Antena 3, S.A.) comenzaron pronto a reclamar a la Administración, primero, y al Tribunal Constitucional, después, el acceso a la actividad televisiva. Consecuencia de este fenómeno fue el surgimiento de una jurisprudencia en el seno del Alto Tribunal favorable a la constitucionalidad del servicio público televisivo, susceptible de dos períodos: un primero, a lo largo de la década de los ochenta, contundentemente a favor de la constitucionalidad de la publicatio y del mismo monopolio de la televisión; y otro, ya en Ios noventa, más propicio a cierta liberalización de la actividad televisiva ${ }^{12}$.

11 La declaración de la actividad televisiva como servicio público de titularidad estatal, contenida en el referido art. $1.2 \mathrm{~L}$ 4/ 1980, se vio ratificada en la posterior legislación dictada al respecto: la $L$ 46/ 1983, de 26 de diciembre, reguladora del Tercer Canal de Televisión; la L 31/ 1987, de 18 de diciembre, de Ordenación de las Telecomunicaciones; la $L$ 10/ 1988, de 3 de mayo, de la Televisión Privada; y la derogada L 35/ 1992, de 22 de diciembre, reguladora de la Televisión por Satélite. Toda esta normativa atribuía, así, al Estado la titularidad del servicio público televisivo, inclusive en el caso de la llamada Ley de la Televisión Privada; no obstante, la L 19/ 1988 supuso ya un importante paso en la liberalización de la actividad televisiva, al ser su objeto "regular la gestión indirecta del servicio público esencial de la televisión cuya titularidad corresponde al Estado" (art. 1).

12 Al respecto de tal jurisprudencia, en general, vid. Gema ROSADO IGLESIAS, "Consideraciones en torno al derecho a crear televisión en la jurisprudencia del Tribunal Constitucional", Derechos y Libertades, núm. 4, 1995, pp. 481 y ss. 
Si bien en el primer período el Tribunal Constitucional admite la constitucionalidad de la televisión privada como una posible opción política del legislador, también lo es, según el Tribunal en su Sentencia 12/ 1982, de 31 de marzo, la publicatio de la televisión, así como el decidir si ésta ha de ser gestionada directa o indirectamente; y esto, por cuanto que la declaración del servicio público televisivo vendría justificada por la intensidad social y política que la actividad televisiva supone en relación al ejercicio de los derechos reconocidos en el artículo 20.1.a y d de la Constitución, frente a los tradicionales medios de masas, en el desarrollo de la vida política y democrática del país (FFJJ núms. 3 a 5$)^{13}$. I gual parecer se mantendría en posteriores pronunciamientos del Constitucional durante los años ochenta, como es el caso de sus Sentencias 74/ 1982, de 7 de diciembre, y 106/ 1986, de 24 de junio'14. La posterior legislación dictada al respecto ratificaría dicha declaración ( $\mathrm{L}$ 46/ 1983, de 26 de diciembre, y L 31/ 1987, de 18 de diciembre), aunque supuso cierta liberalización de la televisión a nivel estatal por ondas terrestres ( $\mathrm{L}$ 10/ 1988, de 3 de mayo) y, más tarde, por satélite ( $\mathrm{L}$ 35/ 1992, de 22 de diciembre) ${ }^{15}$. Así, aunque sin llegar a reconocer un derecho a la actividad televisiva, se permitió la gestión indirecta del servicio público esencial de la televisión, cuya titularidad seguía correspondiendo al Estado, y de esta forma que las Ilamadas "televisiones privadas" no sean, desde entonces, sino meras empresas concesionarias de la gestión indirecta del servicio público esencial de la televisión, de manera que lo liberalizado realmente fue una parcela de la gestión del servicio público de la televisión (televisión hertziana y por satélite de ámbito nacional, en aquel momento) ${ }^{16}$.

\footnotetext{
${ }^{13}$ La estimación por el Tribunal de otras limitaciones impuestas por el ejercicio de la actividad televisiva, no lo son tanto, a la postre, al partir éstas principalmente de condicionamientos técnicos superables y, por ello, de menos entidad jurídica. Más importante en esta Sentencia es la concepción institucional que ofrece el Constitucional en relación a los derechos contenidos en el art. 20.1.a y d CE, verdadero fundamento del razonamiento del Tribunal, y clave en la posterior jurisprudencia dictada al efecto, en este primer período.
}

14 En esta primera jurisprudencia del Tribunal Constitucional español tuvo especial eco las consecuencias derivadas del proceso liberalizador, a la vez que desregularizado, de la televisión en Italia, en el que la Corte Constitucional italiana desempeñara un primerísimo papel; al respecto, cfr. Enrique GARCÍA LLOVET, El régimen jurídico de la televisión... cit., p. 206. Acerca de la jurisprudencia constitucional italiana sobre la televisión, y del proceso liberalizador abierto en torno a ésta, vid. Remedio SÁNCHEZ FERRIZ, "La jurisprudencia del Tribunal Constitucional italiano sobre la televisión", Revista de Derecho Público, núms. 108-109, 1987, pp. 565 y ss.

15 Según lo apuntado en anterior nota a pié.

${ }^{16}$ Cfr. José Carlos LAGU NA DE PAZ, “La televisión privada”, en www.iustel.com ( 30/ 01/ 2009). 
La anterior situación varió notablemente en la década de los noventa de acuerdo a la nueva jurisprudencia constitucional surgida en torno al servicio público televisivo. Las Sentencias del Tribunal Constitucional 206/ 1990, de 17 de diciembre, 189/ 1991, de 3 de octubre, y 31/ 1994, de 31 de enero, vendrían a ser como fases de un hipotético proceso donde la primera establecería las bases de una nueva concepción acerca del servicio público televisivo, la segunda las opciones posibles de desarrollo de tal concepción, y la tercera, parecería, la conclusión. Efectivamente, la 206/ 1990 introdujo una idea que se repetiría en las otras Sentencias: la declaración de una actividad como servicio público no concede, ahora, plena discreción al legislador para que establezca el régimen jurídico que estime más adecuado, pues está condicionado por los derechos y libertades afectados por dicha declaración, por las razones que la justifican y por el pluralismo (FJ núm. 6). Por otra parte, la 189/ 1991 estableció las dos opciones que sobre la declaración de servicio público de la televisión por cable y de ámbito local se daban respecto a la Constitución en aquel momento: o bien se enjuiciaba como inconstitucional por injustificada, o en su caso se adecuaba a las limitaciones más arriba indicadas (FJ núm. 3). Y la 31/ 1994 aceptó el servicio público de la televisión local por cable, siempre y cuando éste respetara el contenido esencial del derecho fundamental a la libertad de expresión y de comunicación garantizada en el artículo 20.1.a y d de la Constitución; de no ser así, como sucedió en los amparos elevados al Constitucional en esta ocasión, dicha publicatio perdía su justificación constitucional, concediéndose por el Tribunal el amparo solicitado (FJ núm. 7) ${ }^{17}$.

Pero es con la Sentencia 127/ 1994, de 5 de mayo, cuando tal jurisprudencia alcanza su máximo desarrollo al incidir y profundizar en la idea del pluralismo externo (según se ha apuntado), en conexión con el mercado televisivo y el derecho a recibir información, como base de una nueva comprensión del régimen jurídico-constitucional de la actividad televisiva. Respecto al pluralismo externo y al mercado televisivo, el Tribunal afirma que tan odioso resulta un monopolio privado de televisión, "desde la perspectiva de la exclusión del ejercicio de los derechos de otros, que el monopolio público ya

${ }^{17}$ En este sentido, el Constitucional denuncia el excesivo silencio legislativo mantenido en relación a la televisión local por cable como causa del amparo, en cuanto que limitativo de la libertad de expresión y comunicación. Posteriores Sentencias del Tribunal ratificarían tal parecer (SSTC 47, 98, 240, 281 y 307/ 1994, más 12/ 1995 y 47/ 1996), sin perjuicio de peculiares pronunciamientos en los que se apartase de tal comprensión, como es el 88/ 1995, de 6 de junio (sobre la televisión local por ondas terrestres, precisamente). Al respecto de éste, vid. las críticas vertidas por José María SOUVIRÓN MORENILLA, "En torno a la regulación de la televisión local por ondas terrestres y algunas cuestiones conexas", Revista de Estudios de la Administración Local y Autonómica, núm. 269, 1996, pp. 45 a 48. 
abandonado, en virtud del no descartable riesgo de abusos en el mercado a causa de posiciones dominantes y prácticas restrictivas de competencia por singulares poderes económicos". De este modo, evitar las concentraciones monopolísticas públicas o privadas de los medios televisivos, para así impedir posiciones hegemónicas en el mercado, requiere de una efectiva tutela y garantía del pluralismo externo (FJ núm. 6.C). Y sobre la conexión existente entre pluralismo externo y derecho a la información, el Constitucional identifica, ahora, "un derecho fundamental de los ciudadanos en cuanto espectadores a recibir una información libre y pluralista a través de la televisión" (FJ núm. 6.D).

La respuesta del legislador estatal a esta nueva jurisprudencia constitucional no se haría esperar, a la vista de las L eyes 37/ 1995, de 12 de diciembre, de Telecomunicaciones por Satélite, 41/ 1995, de 22 de diciembre, de Televisión Local por O ndas Terrestres (especialmente, en relación a estas páginas), y 42/ 1995, de 22 de diciembre, de las Telecomunicaciones por Cable. Con ellas, además de haberse regulado por primera vez la televisión local y por cable, se dio un notabilísimo salto en la liberalización de la actividad televisiva a través de satélite y cable ${ }^{18}$. Posteriormente otras disposiciones han venido a profundizar en la liberalización televisiva. Las primeras fueron el Real Decreto-Ley 6/ 1991, de 7 de junio, de Liberalización de las Telecomunicaciones ${ }^{19}$, la Ley 17/ 1997, de 3 de mayo, por la que se incorpora al Derecho español la Directiva 95/ 47/ CE, de 24 de octubre, del Parlamento Europeo y del Consejo sobre el uso de normas para la transmisión de señales de televisión y se aprueban medidas adicionales para la liberalización del sector ${ }^{20}$, y el Real De-

${ }^{18}$ Respecto a la televisión por satélite, la L 37/ 1995 partía de un nuevo marco jurídico para las telecomunicaciones por satélite según el cual la prestación de tales servicios quedaría, en general, liberalizada al requerirse únicamente para su ejercicio de autorización administrativa (arts. 1 y 3). Y en cuanto a la televisión por cable, declarado el servicio de telecomunicaciones por cable como servicio público, si bien encomendando su gestión indirecta a operadores particulares (arts. 1 a 9) , la L 42/ 1995 reservaba un mínimo de un cuarenta por ciento del total de la oferta audiovisual a unos programadores independientes que no requerirían para el ejercicio de su actividad ni de autorización administrativa (arts. 9.1.e, 10 y 11.1.d).

19 Por el que: se creó la Comisión del Mercado de las Telecomunicaciones (art. 1), como garantía de los principios de libre competencia, transparencia e igualdad de trato por parte de todos los partícipes en el mercado de las telecomunicaciones (y RD 1994/ 1996, de 6 de septiembre, por el que se aprueba el Reglamento de la Comisión del Mercado de las Telecomunicaciones); se modificaron ciertos preceptos de la L 31/ 1987 (art. 2) y la L 42/ 1995 (art. 3); y se concibió un segundo operador de telecomunicaciones a través de RETEVISIÓN (art. 4).

20 La L 17/ 1997, al amparo del pluralismo externo y del derecho recibir información plural, de un lado, y de la normativa comunitaria en materia de televisión, de otra, regulaba determinados aspectos de la televisión por satélite con tecnología digital y la televisión emitida por el siste- 
creto 2169/ 1998, de 9 de octubre, por el que se aprueba el Plan técnico nacional de la televisión digital terrestre (naciendo las televisiones digitales terrestres gestionadas por entidades privadas). Y en un segundo bloque: la Ley 53/ 2002, de 30 de diciembre, de Medidas Fiscales, Administrativas y del Orden Social, modificando las anteriores Leyes 10/ 1988 y 41/ 1995; la Ley $32 / 2003$, de 3 de noviembre, General de Telecomunicaciones (derogando la L 42/ 1995); la Ley 62/ 2003, de 30 de diciembre, de Medidas Fiscales, Administrativas y del Orden Social, modificando nuevamente las Leyes 10/ 1988 y 41/ 1995); el Real Decreto 439/ 2004, de 12 de marzo, por el que se aprueba el Plan técnico nacional de la televisión digital local; la Ley 10/2005, de 14 de junio, de Medidas U rgentes para el Impulso de la Televisión Digital Terrestre, de Liberalización de la Televisión por Cable y de Fomento del Pluralismo; el Real Decreto 944/ 2005, de 29 de julio, por el que se aprueba el Plan Técnico nacional de la televisión digital terrestre (derogando al anterior RD 2169/ 1998), completado por el 945/ 2005, también de 29 de julio, por el que se aprueba el Reglamento general de prestación del servicio de televisión digital terrestre; la Ley 17/ 2006, de 5 de junio, de la radio y la televisión de titularidad estatal (derogando la anterior L 4/ 1980); la Ley 56/ 2007, de 28 de diciembre, de Medidas de I mpulso de la Sociedad de la Información; y más recientemente, el Real Decreto-Ley 1/ 2009, de 23 de febrero, de medidas ur-

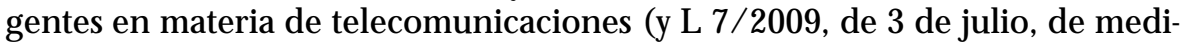
das urgentes en materia de telecomunicaciones, procedente del anterior DL 1/ 2009, de 23 de febrero), el Real Decreto-Ley 11/ 2009, de 13 de agosto, por el que se regula, para las concesiones de ámbito estatal, la prestación del servicio de televisión digital terrestre de pago mediante acceso condicional, y la Ley 8/ 2009, de 28 de agosto, de financiación de la Corporación de Radio y Televisión Española (modificando la referida L 17/ 2006) ${ }^{21}$.

ma de acceso condicional (exposición de motivos) : aprobación de la incorporación al Derecho español de las especificaciones técnicas contenidas en la Directiva 95/ 47/ CE sobre uso de normas para la transmisión de señales de televisión (art. 1), situaciones de dominio de mercado (art. 2), supuestos especiales de autorización para la prestación de servicios de televisión por satélite (art. 3), obligaciones de los prestadores de servicios de difusión de televisión digital que reciban contraprestaciones económica de los usuarios (art. 4) , requisitos aplicables a los servicios de televisión (art. 5), conexión de interfaz abierto en los aparatos receptores de televisión (art. 6), requisitos aplicables al acceso condicional a los servicios de televisión digital (art. 7), etc.

21 Para una primera aproximación al todavía vigente marco normativo de la televisión, vid., con carácter general, Enrique LINDE PANIAGUA, José María VIDAL BELTRÁN y Sara MEDINA GONZÁLEZ, Derecho audiovisual... cit., pp. 28 y ss. 


\section{II.C.- TELEVISIÓN YESTADO AUTONÓMICO}

En cuanto a la distribución competencial existente entre el Estado y las Comunidades Autónomas al respecto de la televisión, y especificando en la local, su régimen jurídico final es resultado del entramado normativo complejo del Derecho estatal y del autonómico a tales efectos. Así, y conforme a la Constitución, su artículo 149.1.27 reserva al Estado las normas básicas del régimen de la televisión ("y, en general, de todos los medios de comunicación social"), "sin perjuicio de las facultades que en su desarrollo y ejecución correspondan a las Comunidades Autónomas" (a lo que se ha de estar a sus respectivos Estatutos de Autonomía); mientras que, de otro lado, el 149.1.21 reserva al Estado la competencia exclusiva en materia de telecomunicaciones y radiocomunicación. Al respecto el Tribunal Constitucional ha procurado una interpretación equilibrada de ambos preceptos, de manera que el carácter exclusivo del segundo no desapodere un ámbito competencial propio de las Comunidades Autónomas (de acuerdo a sus respectivos Estatutos) en relación a la televisión. De este modo, el Tribunal determina una interpretación restrictiva del artículo 149.1.21 en relación con la ordenación y gestión de la actividad televisiva respecto a la utilización de infraestructuras, de manera que las competencias estatales queden limitadas a la regulación de los extremos técnicos del soporte: es decir, la ordenación y el régimen de utilización del dominio público radioeléctrico, pero sin alcanzar la gestión de las actividades que discurran sobre él; y de esta forma, garantizándose la competencia autonómica de desarrollo legislativo y ejecución de las bases estatales sobre televisión, conforme al artículo 149.1.27 de la Constitución, y por tanto, concretamente, la atribución a las Comunidades Autónomas de las competencias para otorgar las concesiones de radio y televisión cuando estas actividades se desarrollen en el ámbito territorial de una Comunidad (SSTC 167 y 168/ 1993, de 27 de mayo) , o para autorizar la instalación de antenas y equipos de recepción de las señales de televisión por satélite (STC 244/ 1993, de 15 de julio) ${ }^{22}$.

En cuanto a las previsiones estatutarias en torno a la televisión ( y dejando a un lado, por ahora, las más recientes reformas de Estatutos de Autonomía

22 Con carácter general, vid. Francisco LÓPEZ MENUDO, Concepción BARRERO RODRíGUEZ, y Juan Antonio CARRILLO DONAIRE, "Reparto de competencias Estado-CCAA: Industria, comercio, infraestructuras y transportes", en www.iustel.com (30/ 01/2009); también de interés, Manuel CONCHA JARABA, "Los medios de comunicación social”, en AAVV Desarrollo de las competencias del Estatu to de Au ton omía para Andalucía, Consejería de Relaciones Institucionales (Junta de Andalucía), Sevilla, 2001, pp. 591 y ss. 
llevadas a cabo), una vez superada al tiempo las limitaciones competenciales que suponían los diversos sistemas de acceso a la autonomía ( tras sucesivas reformas estatutarias), puede afirmarse una progresiva homogeneización en los Estatutos de los títulos competenciales relativos a la actividad televisiva ${ }^{23}$. Así, y con carácter general, éstos han asumido competencias de desarrollo legislativo y ejecución sobre medios de comunicación en el marco de la legislación básica estatal, y en algunos casos específicamente en materia de televisión y previendo, incluso, la creación de medios televisivos propios [art. 16 y disp. trans. 3a LO 6/ 1981, de 30 de diciembre (EA); art. 37 LO 8/ 1982, de 10 de agosto (EAr); art. 17 LO 7/ 1981, de 30 de diciembre (EAst); art. 10 LO 2/ 1983, de 25 de febrero (EB); art. 16 LO 4/ 1979, de 18 de diciembre (EC); art. 34.7 LO 4/ 1983, de 25 de febrero (ECL); art. 32 LO 10/ 1982, de 10 de agosto (ECan); arts. 25.9 y 29 LO 8/ 1981, de 30 de diciembre (ECant); arts. 32.9 y 38 LO 9/ 1982, de 10 de agosto (ECM); art. 8.10 y disp. adic. 5á LO Ley Orgánica 1/ 1983, de 25 de febrero (EE); art. 34 LO 1/ 1981, de 6 de abril (EG); art. 27.11 LO 3/ 1983, de 25 de febrero (EM); arts. 11 y 14 LO 4/ 1982, de 9 de junio (EM ur); art. 19 LO 3/ 1979, de 18 de diciembre (EPV); art. 37 LO 5/ 1982, de 1 de julio (EV); y art. 44 LO 13/ 1982, de 10 de agosto (LORAFNA) ] ${ }^{24}$. Al amparo de tal marco competencial, y de la legislación básica estatal dictada al respecto, las Comunidades Autónoma han participado en la actividad de la televisión pública en el ámbito de sus respectivos territorios, han creado sus propios medios televisivos, han desarrollado normas estatales en relación a actividad televisiva de ámbito inferior a las Comunidades, y han creado Consejos Audiovisuales ${ }^{25}$.

${ }^{23} \mathrm{Al}$ respecto, vid. Ángel RODRÍGUEZ, "Medios de comunicación social y publicidad", en AAVV R eformas estatutarias y distribución de competencias, Francisco Balaguer Callejón (dir.), Luis Ortega, Gregorio Cámara Villar y José Antonio Montilla Martos (coords.), Instituto Andaluz de Administración Pública, Sevilla, 2007, pp. 750 y ss.

${ }^{24}$ Con carácter general, vid. Santiago MUÑOZ MACHADO, Derecho Público de las Comunidades Autónomas (I), 2ª ed., I ustel, Madrid, 2007, pp. 843 y ss.

25 Sólo a nivel legislativo (y sin perjuicio de sus ulteriores reformas) : L 5/ 1982, de 20 de Mayo, de creación del Ente Público Radio Televisión Vasca; L del Principado de Asturias 5/ 1983, de 4 de agosto, reguladora del Consejo Asesor de Radio y Televisión Española en el Principado de Asturias (derogada por la $L$ del Principado de Asturias 4/ 2007, de 9 de noviembre); L 1/ 1984, de 27 de febrero, reguladora del Consejo Asesor de Radiotelevisión Española en Cantabria (derogada); L 5/ 1984, de 7 de marzo, reguladora del Consejo Asesor de Radio y Televisión Española en la Comunidad de Madrid; L 4/ 1984, de 26 de junio, reguladora del Consejo Asesor de Radio-Televisión Española en Aragón; L 13/ 1984, de 30 de junio, de creación, organización y control par- 
Sin embargo la anterior homogenización competencial parece retraerse con las últimas reformas estatutarias, dada la mayor concreción competencial a la que en algunos casos se llega, al singularizarse las facultades sobre las que se asumen competencias sobre una concreta materia (especialmente, Cataluña y Andalucía) ${ }^{26}$. De este modo, y en relación a la televisión, además de la competencia exclusiva autonómica en fomento y difusión de la producción audiovisual, se encuentra: la competencia exclusiva sobre la organización de

lamentario del Ente público de Radio-Televisión Madrid; L 7/ 1984, de 4 de julio, de creación de la Entidad Pública RTVV y regulación de los servicios de radiodifusión y televisión de la Generalidad Valenciana; L 8/ 1984, de 11 de diciembre, de Radiodifusión y Televisión en la Comunidad Autónoma de Canarias; L 9/ 1984, de 11 de julio, de creación de la Compañía de Radio-Televisión de Galicia; L 7/ 1985, de 22 de mayo, de creación de la Compañía de Radio y Televisión de Ias Islas Baleares; L Foral 1/ 1986, de 20 de febrero, de modificación de la Ley Foral de creación y regulación del consejo asesor de radio televisión española en Navarra; L 8/ 1987, de 15 de abril, de creación, organización y control parlamentario de la Corporación Aragonesa de Radio y Televisión; L 1/ 1987, de 7 de abril, sobre el Consejo Asesor de Radio y Televisión Española en CastiIla-La Mancha; L 8/ 1987, de 9 de diciembre, de creación de la Empresa Pública de la Radio y Televisión de Andalucía y regulación de los servicios de radiodifusión y televisión gestionados por la Junta de Andalucía (derogada por la actual L 18/2007, de 17 de diciembre, de la radio y televisión de titularidad autonómica gestionada por la Agencia Pública Empresarial de la Radio y Televisión de Andalucía); L 2/ 1989, de 10 de marzo, para la formación de un texto único del conjunto de Leyes que regulan la creación, composición y funcionamiento del Consejo Asesor de Radiotelevisión Española en Castilla y León; L 7/ 1994, de 17 de noviembre, por la que se extingue Radio Televisión Murciana y se regula el servicio público de radiodifusión de la Región de Murcia, su organización y control parlamentario (derogada por la L 9/ 2004, de 29 de diciembre, sobre Creación de la Empresa Pública Regional Radio Televisión de la Región de Murcia); L 3/ 2000, de 26 de mayo, de Creación del Ente Público de Radio-Televisión de Castilla-La Mancha; L 2/ 2000, de 8 de junio, del Consejo Asesor de Radiotelevisión Española en Extremadura; L 4/ 2000, de 16 de noviembre, por la que se crea la empresa pública Corporación Extremeña de Medios Audiovisuales; L 2/ 2001, de 18 de abril, de Contenidos Audiovisuales y Servicios Adicionales (y L 2/ 2006, de 21 de junio, de Supresión del Consejo Audiovisual de la Comunidad de Madrid); L Foral 18/2001, de 5 de julio, por la que se regula la actividad audiovisual en $N$ avarra y se crea el Consejo Audiovisual de Navarra; L del Principado de Asturias 2/ 2003, de 17 de marzo, de Medios de Comunicación Social; L 1/ 2004, de 17 de diciembre, de creación del Consejo Audiovisual de Andalucía; L 22/ 2005, de 29 de diciembre, de la comunicación audiovisual de Cataluña; L 1/ 2006, de 19 de abril, de la Generalitat, del Sector Audiovisual; L del Principado de Asturias 6/ 2006, de 20 de junio, de Comunicación y Publicidad Institucionales; L 10/ 2007, de 29 de marzo de 2007, de Medios Audiovisuales de Castilla-La Mancha; L 11/2007, de 11 de octubre, de la Corporación Catalana de Medios Audiovisuales; y L 3/ 2008, de 16 de junio, reguladora de la Empresa Pública "Corporación Extremeña de Medios Audiovisuales".

${ }^{26}$ Vid. Carles VIVER I PI-SU NYER, Francisco BALAGUER CALLEJÓN y Javier TAJADU RA TEJADA, L a reforma de los estatutos de autonomía: con especial referencia al caso de Cataluña, Centro de Estudios Políticos y Constitucionales, Madrid, 2005. 
la prestación del servicio público de comunicación audiovisual de la Comunidad Autónoma y de los servicios públicos de comunicación audiovisual de ámbito local (respetando la garantía de la autonomía local), y la competencia compartida sobre la regulación y el control de los servicios de comunicación audiovisual que utilicen cualquiera de los soportes y tecnologías disponibles dirigidos al público de la respectiva Comunidad, así como sobre las ofertas de comunicación audiovisual si se distribuyen en el territorio de la Comunidad; y también, la creación y mantenimiento de los medios de comunicación social necesarios para el cumplimiento de los fines de la Comunidad [ arts. 127.1.d y 146.1 LO 6/ 2006, de 19 de julio (EC); art. 30.26 LO 1/ 2007, de 28 de febrero (EB); arts. 68.1y 69 LO 2/ 2007, de 19 de marzo (EA); art. 74 LO 5/ 2007, de 20 de abril (EAr) ; y arts. 70.31.c y 71.12, y disp. adic. 3a LO 14/ 2007, de 30 de noviembre $(E C L)]$.

Asimismo los nuevos Estatutos de Autonomía han introducido derechos y principios rectores ${ }^{27}$, de manera que pasan a definir sustantivamente el ejercicio del poder de las Comunidades Autónomas en el ámbito de sus respectivas competencias, promoviendo, en relación a la actividad televisiva: Ias condiciones que garanticen el derecho a la información y a recibir de los medios de comunicación una información veraz y unos contenidos que respeten la dignidad de las personas y el pluralismo político, social, cultural y religioso; y las condiciones que garanticen el acceso sin discriminación a los servicios audiovisuales en el ámbito de la respectiva Comunidad [ arts. 43.3, 52 y 146.3 LO 6/ 2006 (EC); art. 34 LO 2/ 2007 (EA); arts. 28.2 y 3 LO 5/ 2007 (EAr); y arts. 16.21 y 22 LO 14/ 2007 (ECL) ]. A tales efectos, además, han institucionalizado a nivel estatutario Consejos Audiovisuales autonómicos ( $\sin$ perjuicio de que ya estuvieran creados a nivel legislativo), cuya función es velar por el respeto de los derechos, las libertades y los valores constitucionales y estatutarios

27 Sobre la constitucionalidad, naturaleza y alcance de tales derechos y principios estatutarios, cfr. STC 247/ 2007, de 12 diciembre. Y acerca de dicha STC, al respecto, vid.: Tomás de la QUADRA-SALCEDO JANINI, "EI régimen jurídico de los derechos sociales estatutarios. Reflexiones tras la STC 247/ 2007, de 12 de diciembre", Revista General de Derecho Constitucional, núm. 5, 2008 (48 pp.), en www.iustel.com (06/ 05/ 2008); Francisco LÓ PEZ MENUDO, "Los derechos sociales en los Estatutos de Autonomía", en IV Congreso de la A sociación Española de Profesores de Derecho Administrativo (Valladolid, 6 y 7 de febrero de 2009), 97 pp., en www.uclm.es/ ceuropeos/ aepda/ actividades/ congresos/ congresolV (19/03/ 2009); y Gregorio CÁMARA VILLAR, "Los derechos estatutarios no han sido tomados en serio (A propósito de la STC 247/ 2007, de 12 de diciembre, sobre el Estatuto de Autonomía de la Comunidad Valenciana)", Revista Española de Derecho Constitucional, núm. 85, 2009, pp. 259 y ss. 
en el ámbito de la comunicación y los medios audiovisuales en la respectiva Comunidad [art. 56.3 LO 5/ 1982, conforme LO 1/ 2006, de 10 de abril (EV); art. 82 LO 6/ 2006 (EC); art. 77 LO 1/ 2007 (EB); y art. 131 LO 2/ 2007 $(E A)]^{28}$. E incluso, en algún caso, han previsto un Título específico relativo a los medios de comunicación, y en el que integran expresamente aspectos relativos a la actividad televisiva [Tít. V (arts. 88 a 92) LO 1/ 2007 (EB); y Tít. VIII (arts. 207 a 217) LO 2/ 2007 (EA) ].

\section{LA LEY DE TELEVISIÓN LOCAL TERRESTRE}

\section{III.A.- LA LEY 41/ 1995 DE TELEVISIÓN LOCAL POR ONDAS TERRESTRES}

Concretando ya en la Ley 41/ 1995, de 22 de diciembre, para la Televisión Local por Ondas Terrestres, ésta supuso un paso fundamental para tal tipo de televisión por cuanto que ofrecía por primera vez una regulación jurídica de la misma, aunque dicha Ley no alcanzara, en cambio, la liberalización prevista en tal momento para las televisiones por satélite y por cable (conforme $L$ 37/ 1995 y L 42/ 1995, según se ha apuntado) ${ }^{29}$.

Definida la televisión local por la Ley 41/ 1995 por su emisión en abierto ("sin contraprestación económica directa"), su condición técnica analógica ( en cuanto que llevada a cabo a través "de ondas electromagnéticas") y su ámbito municipal (arts. 1 y 3.1$)^{30}$, es declarada servicio público (mas sin expre-

\footnotetext{
${ }^{28} \mathrm{Al}$ respecto de tales Consejos, por ejemplo, vid. Emilio GUICHOT REINA y Juan Antonio CARRILLO DONAIRE, "EI Consejo Audiovisual de Andalucía", Revista Catalana de Dret Públic, núm. 34, 2007, pp. 273 y ss.

${ }^{29}$ Nótese cómo, con esto, la L 41/ 1995 parece encontrarse descontextualizada en relación a sus contemporáneas 37 y 42/ 1995, lo cual destaca aún más si tenemos en cuenta que las tres simularían formar un paquete normativo, por cuanto que fueron elaboradas y publicadas casi simultáneamente. Muestra evidente de ello es, por ejemplo, la mención que hace la L 41/ 1995 en su preámbulo a la L 35/ 1992 (reguladora de la televisión por satélite) como norma aún vigente, cuando ésta se encontraba ya derogada a la entrada en vigor de aquélla (disposición derogatoria L 37/ 1995).

30 "Se entiende por tal aquella modalidad de televisión consistente en la emisión o transmisión de imágenes no permanentes dirigidas al público sin contraprestación económica directa por medio de ondas electromagnéticas propagadas por una estación transmisora terrenal en el ámbito territorial" de cada núcleo urbano principal de población del Municipio correspondiente.
} 
sarse estatal), si bien previendo su gestión indirecta (arts. 1 a 5 , y 9.1 y 13); sin embargo, el grado de liberalización supuesto por dicha gestión indirecta resultaba bastante limitado en atención al escaso número de concesiones previstas para cada Municipio: hasta dos, y siendo una pública, y otra particular (en su caso): El artículo 4 de la Ley 41/ 1995 preveía en principio una única televisión por cada ámbito territorial municipal (conforme art. 3), sin perjuicio de que pudiera llegarse hasta dos si la segunda no resultaba incompatible con las disponibilidades del espectro radioeléctrico; y ello, reservándose la primera concesión al correspondiente Municipio (art. 9.1). De este modo, la gestión del servicio de televisión local terrestre podía corresponder a los propios Municipios y a personas naturales o jurídicas, con o sin ánimo de lucro (art. 5); pero en ambos casos, previa obtención de la correspondiente concesión por la respectiva Comunidad Autónoma (art. 9.1) ${ }^{31}$. Por tanto, el grado de liberalización y pluralismo externo permitido por la Ley 41/ 1995 no parecía resultar muy amplio, pues: cuantitativamente, sólo dos televisiones locales cabrían por Municipio como máximo; y cualitativamente, una de ellas sería pública, mientras que la otra, particular (en su caso).

Sobre el aspecto cuantitativo, bien cabría argumentar que el número total de canales por M unicipio sería superior, ya que a las tel evisiones locales habría que añadirse las públicas nacionales, las autonómicas, y las privadas nacionales (además de las posibles a través de satélite y cable); pero concretando en la televisión estrictamente local (aquélla que verdaderamente afecta a los ciudadanos en relación a sus intereses locales sociales, políticos, culturales, etc., y a los fines de estas páginas), la oferta televisiva se reducía a dos, y ello sin que el legislador hubiera ofrecido razón alguna que justificara dicho número ${ }^{32}$. Por otra parte, cualitativamente nótese que hablamos, al igual que ha-

${ }^{31}$ De este modo, los Municipios podían acordar la gestión indirecta por sí del servicio de televisión local por ondas, dentro del plazo que a estos efectos hubieran señalado sus correspondientes Comunidades.

32 Es más, el número máximo de dos quedaba condicionado a las disponibilidades del espacio radioeléctrico (preámbulo y art. $4 \mathrm{~L}$ 41/ 1995), por lo que éste podía incluso verse reducido. Por otra parte, en la $L$ 10/ 1988, por ejemplo, el número de televisiones privadas a nivel nacional quedaba reducido a tres en razón a cálculos de viabilidad económica, entre otros motivos ( preámbulo); al respecto, cfr. STC 127/ 1994 (FJ núm. 7, in fine). E incluso en la L 42/ 1995 el legislador ofrece argumentos, también de índole económica, para limitar el número de concesiones para el ejercicio del servicio público de telecomunicaciones por cable (preámbulo). Al margen de que se esté de acuerdo o no con tales motivos, lo cierto es que en la L 41/ 1995 el legislador ni siquiera en- 
cía la Ley, de gestión indirecta "particular" y no de "privada" (art. 13); esto es debido a la preferencia que otorgaba la norma a las entidades sin ánimo de lucro para la concesión administrativa, frente al resto de personas físicas y jurídicas que concurrieran a concurso (art. 13.2) ${ }^{33}$. Y es que el ejercicio de la televisión a nivel local, según se ha adelantado, no requería de tan cuantiosos costos como los necesarios para las otras modal idades televisivas, por lo que resultaba justificado que se fomentara en este ámbito un tipo de televisión menos mercantil y más próximo a las libertades de comunicación contenidas en el artículo 20.1.a y d de la Constitución ${ }^{34}$.

Pero la Ley no distinguía entre los diferentes fines no económicos posibles, de modo que eran las Comunidades Autónomas las Ilamadas a graduar la valoración positiva enunciada. Al respecto, el artículo 6 introducía algunos principios inspiradores de la prestación del servicio público de la televisión local, capaces a su vez de permitir cierta guía para los poderes públicos; eran el respeto de la igualdad (art. 6.f), y la promoción de los intereses, la cultura y la convivencia local (art. 6.g). Estos principios, aunque más dirigidos a ordenar la actuación de los concretos gestores del servicio público televisivo local que la de las Comunidades Autónomas responsables del mismo (con arreglo a la

traba a darlos, lo que suponía una limitación injustificada del ejercicio de los derechos de los ciudadanos (arts. 20.1.a y d, 38 CE, y 53.1 CE); en este sentido, la STC 26/ 1981, de 17 de julio, recuerda que "la motivación es no sólo una elemental cortesía, sino un riguroso requisito del acto de sacrificio de los derechos" (FJ núm. 13). De similar parecer es Javier GARCÍA ROCA, quien, en relación al todavía Proyecto de Ley de Televisión Local, criticaba la reducción a una concesión por Municipio, así como la falta de justificación de tal limitación por el legislador en tanto que restricción desproporcionada al ejercicio de derechos fundamentales y violación del pluralismo informativo ( "Límites constitucionales al legislador de la Televisión", Revista Andaluza de Administración Pública, núm. 24, 1995, pp. 34 y 36).

${ }^{33}$ Cabe preguntarnos por la constitucionalidad de dicha preferencia, en tanto que el acceso al ejercicio de la actividad televisiva debe estar presidido por el principio de igualdad (STC 127/ 1994, FJ núm. 6.B); de partida dicha distinción no parecía objetable, por cuanto que es coherente con la concepción constitucional de actividad televisiva mantenida a partir de las libertades de expresión e información (libertad de antena, art. 20.1.a y d CE), frente a la sostenida desde la libertad de empresa (televisión privada, art. 38). Al respecto, cfr. Juan Francisco SÁNCHEZ BARRILAO, "EI derecho fundamental a la actividad televisiva (I) y (II) ... cit., pp. 38 y 39 , y 605 y ss. (respectivamente).

34 Pero, y de ser así, ello casaba mal con la reducción de sólo una concesión a particulares por Municipio, pues suponía limitar, paradójicamente, en extremo lo que precisamente se quería fomentar: las libertades de comunicación contenidas en el art. 20.1.a y d CE. 
dicción del precepto en su conjunto) ${ }^{35}$, se presentaban no obstante como criterios útiles en tanto que conformes al artículo 149.1.1 de la Constitución y adecuados al marcado carácter local de esta modalidad televisiva; y ello, aún más, dado el carácter básico de la Ley 41/ 1995 en relación al artículo 149.1.21 y 27 de la Constitución y a la legislación autonómica a dictar al efecto ${ }^{36}$. De otra parte, la Ley prohibía expresamente que las televisiones locales formaran parte de cadenas de televisión (art. 7.1) ${ }^{37}$, a fin de evitar televisiones nacionales o regionales encubiertas, así como que éstas emitiera en cadena (art. 7.3) ${ }^{38}$; sin embargo, esta última prohibición quedaba matizada al preverse que las Comunidades Autónomas competentes pudieran autorizar, previa conformidad de los plenos de los M unicipios afectados, emisiones en cadena en atención a características de proximidad territorial y de identidades sociales y culturales de dichos Municipios ( art. 7.4) ${ }^{39}$.

35 Vid., si no, el resto de apartados del art. 6: objetividad, veracidad e imparcialidad de las informaciones; separación entre informaciones y opiniones, e identificación de aquéllos que sustenten estas últimas; respeto a los límites del art. 20.4 CE; respeto al pluralismo político, religiosos, social, cultural y lingüístico; respeto al honor, la fama, la vida privada de las personas y cuantos derechos y libertades reconoce la CE; y protección de la juventud y de la infancia, conforme con lo establecido en la L 25/ 1994.

\footnotetext{
${ }^{36} \mathrm{~N}$ ada impedía, tampoco, la aparición de otros principios y criterios, pero éstos hubieran debido siempre guardar la oportuna justificación y proporcionalidad con la igualdad y la realidad local y autonómica (cultural, social, económica, etc.).

${ }^{37}$ Entendiéndose a estos efectos que forman parte de una cadena: "aquellas televisiones en las que exista una unidad de decisión, considerándose que esta unidad de decisión existe, en todo caso, cuando uno o varios socios, mediante la agrupación de acciones, ejerzan la administración de dos o más sociedades gestoras del servicio, posean en ésta la mayoría de los derecho de voto, o tengan derecho a nombrar o destituir a la mayoría de los miembros de sus respectivos consejos de administración" (art. 7.2). Esto resulta completado con el art. 13.4: "La concesión obliga a la explotación directa del servicio y será intransferible".
}

38 Se entiende que esto ocurre cuando varias televisiones locales emiten la misma programación durante más del veinticinco por ciento del tiempo total de emisión semanal, aunque fuese en horario diferente.

39 Por tanto, y a diferencia de la televisión por cable, se dificultaba y condicionaba la transformación de programadores particulares en gestores encubiertos de canales de televisión a nivel local, pues, en principio, se prohibía emisiones en cadena, y la posibilidad de autorización de tales emisiones quedaba condicionada a características culturales y sociales comunes del contenido de la programación en relación a los Municipios afectados; sólo de esta forma cabía entender los criterios establecidos por el art. 7 L 41/ 1995 a efecto de autorizar emisiones en cadena, pues no te- 
En cuanto a la situación jurídica en la que quedaban aquéllos que hasta la entrada en vigor de la Ley 41/ 1995 venían desarrollando actividad televisiva de ámbito local (disposición transitoria única), sólo los que vinieran emitiendo antes del 1 de enero de 1995 podían continuar su actividad hasta tanto obtuvieran la correspondiente concesión. Ello suponía ya aceptar que, en aquellos Municipios donde existían varias televisiones locales antes de los respectivos concursos, más de al guna no obtendría la correspondiente concesión y, consecuentemente, tendrían que dejar de emitir en el plazo de ocho meses desde la resolución del oportuno concurso ${ }^{40}$; pero también, y mientras se celebraran dichos concursos, la situación de interinidad jurídica en que tales televisiones locales se encontraban ${ }^{41}$, frente a las que hubieran comenzado a emitir después del 1 de enero de 1995 (antes de la entrada en vigor de la L 41/ 1995), pues éstas quedaban fuera de dicho régimen transitorio. A estos efectos, hay otras dos cuestiones a tratar. La primera es el carácter indefinido con el que se presentaba dicho régimen transitorio, pues la Ley 41/ 1995 no establecía un plazo máximo de vigencia del régimen transitorio (a diferencia

nía sentido que se exigiera proximidad territorial y características comunes territoriales, sociales y culturales, para luego autorizarse emisiones con contenidos de naturaleza generalista o que excedieran ampliamente el marco local afectado. Y sólo de esta forma cabría entender, también, la posibilidad de que las CCAA competentes pudieran, excepcionalmente, "autorizar coberturas que superen el estricto ámbito territorial de una televisión local por ondas terrestres" (art. 3.3). De otra forma, se hubiera estado permitiendo fenómenos de concentración o unificación de la programación emitida por las televisiones locales, y con ello la aparición de verdaderos canales televisivos a niveles superiores al local, e incluso nacional como ocurriera en Italia (sobre la experiencia italiana al respecto, cfr. José Carlos LAGUNA DE PAZ, Régimen jurídico de la televisión privada... cit., pp. 82 y 83$)$.

40 La necesaria obtención de dicha concesión administrativa conforme a una reglamentación inexistente al momento en que tales sujetos iniciaron sus emisiones, obligaba a que tales televisiones locales se adaptaran lo más pronto posible al nuevo régimen jurídico definido por la $\mathrm{L}$ 41/ 1995.

${ }^{41}$ De gran interés al respecto son las manifestaciones del Tribunal Constitucional en su STC 88/ 1995 en relación a cómo, para la televisión local por ondas, no cabían situaciones interinas dado el carácter limitado del espacio radioeléctrico y los abusos que ello podría dar lugar (FJ núm. 7); y esto frente a la prolongada situación de transitoriedad que ha supuesto la ausencia de normativa estatal y autonómica en desarrollo de la L 41/ 1995 (por mucho tiempo, según se ha apuntado ya y se viene más adelante a profundizar), por un lado, y la necesidad de celebración de los oportunos concursos, por otro. Al respecto cfr. el Voto Particular del Magistrado don Manuel Jiménez de Parga. 
del de 3 años, establecido en la $L$ 42/ 1995) ${ }^{42}$, permaneciendo así hasta ocho meses después de la resolución del respectivo concurso concesional en cada uno de los Municipios españoles; de este modo, la efectividad del régimen jurídico diseñado originariamente por la Ley 41/ 1995 ha dependido, a la postre, del desarrollo que del mismo han hecho el Estado y las diversas Comunidades Autónomas al tiempo, dando lugar a una situación fáctica de cuasi desregulación de la actividad televisiva local durante años ${ }^{43}$. Con todo, cabría hablar de una situación de "legalidad a término" de aquellas televisiones local cuya actividad se encontraba sujeta a dicho régimen transitorio ${ }^{44}$. Y la segunda cuestión es cómo, y a diferencia de la Ley 42/ 1995 que sí integraba en su régimen transitorio a todas las televisiones por cable que emitieran antes de su entrada en vigor (disposición transitoria primera), no se entendía ( ni se entiende aún hoy) que sólo las televisiones locales que vinieran emitiendo antes del 1 de enero de 1995 quedaran en tal régimen transitorio, puessi el ánimo del legislador era evitar la aparición de innumerables televisiones locales justo antes de la entrada en vigor de la Ley 41/ 1995 ( y evitar así una situación de entrada masiva de emisores en fraude a la ley), éste debería haber establecido, como hiciera en la Ley 42/ 1995, específicos instrumentos dirigidos a controlar las emisiones ya existentes ${ }^{45}$.

\footnotetext{
42 Que podía llegar a alcanzar hasta un período máximo de 10 años, para los supuestos contemplados en la disposición transitoria primera del Real Decreto-Ley 6/ 1996.

${ }^{43}$ Y así, que "una vez más, lo clandestino se conviert[a] en provisional y tiend[a] a permanecer como definitivo"; cfr. Javier GARCÍA ROCA, "Límites constitucionales al legislador de la televisión... cit., p. 15.

${ }^{44}$ En este sentido, cfr. José VIDA FERNÁNDEZ, “La 'legalidad a término' de la actividad de determinados emisores de televisión local por ondas terrestres: la Sentencia del Tribunal Supremo, Sala de lo Contencioso-Administrativo, Sección Tercera, de 17 de marzo de 2003", Revista General de Derecho Administrativo, núm. 4, 2003, 7 pp., en www.iustel.com (21/ 04/ 2009).

45 Disp. trans. 1a L 42/ 1995, de modo que los emisores debían de: primero, demostrar que se encontraban en explotación antes de la entrada en vigor de la Ley, y ello mediante una inspección de la Administración; y segundo, en el plazo de dos meses debían solicitar una concesión administrativa provisional, previa declaración comprometiéndose a presentarse al concurso que se convoque para la concesión del servicio, que además quedaba limitada temporalmente al período de tres años, como máximo, desde la entrada en vigor de la Ley (ello, naturalmente, salvo lo previsto en la disposición transitoria primera del Real Decreto-Ley 6/ 1996).
} 


\section{III.B.- EL PROYECTO LIBERALIZADOR DE 1997 DE REFORMA DE LA LEY 41/ 1995}

El 31 de enero de 1997 el Consejo de Ministros aprobó la remisión a las Cortes Generales de un Proyecto de Ley de modificación de la Ley 41/ 1995 de Televisiones Locales (121/ 000028) ${ }^{46}$; mas, finalmente, dicho Proyecto sería retirado ( 3 de septiembre de 1997) ${ }^{47}$. Sin embargo, en atención a las importantes modificaciones que en relación a la televisión local conllevaba, es por lo que le dediquemos las siguientes notas ${ }^{48}$.

El referido Proyecto de Ley suponía una importante reforma del régimen jurídico de la televisión local por cuanto que liberalizaba en alto grado la actividad televisiva en este ámbito. A grosso modo, el Proyecto pretendía adaptar la televisión local al proceso de liberalización del mercado de las telecomunicaciones y hacer efectivos los principios de igualdad, transparencia, no discriminación y libre competencia. A tales efectos, modificaba la naturaleza jurídica del servicio de la televisión local, el cual perdía el carácter de servicio pú-

\footnotetext{
${ }^{46}$ A su vez, el 11 de febrero de 1997 la Mesa del Congreso de los Diputados encomendó su aprobación con competencia legislativa plena a la Comisión de Infraestructuras del Congreso (art. $148 \mathrm{RC}$ ), así como su publicación y la apertura de un período de enmiendas de quince días, prorrogado, a la postre, hasta el día 8 de abril de 1997 [BOLETÍN OFICIAL DE LAS CORTES GENERALES. CONGRESO DE LOS DIPUTADOS (VI Legislatura), Serie A: Proyectos de Ley, 17 de febrero de 1997, núm. 30-1, pp. 1 y ss.]. En este período se presentaron 97 enmiendas, de las cuales dos fueron a la totalidad y una de éstas, además, con texto alternativo (núm. 6, Grupo Federal IU-IC) [ la otra enmienda a la totalidad fue la del Grupo Socialista (núm. 39). Al respecto de todas las enmiendas presentadas por los diversos Grupos Parlamentarios del Congreso, vid. BOLETÍN OFICIAL DE LAS CORTES GENERALES. CONGRESO DE LOS DIPUTADOS (VI Legislatura), Serie A: Proyectos de Ley, 14 de abril de 1997, núm. 30-8; también, su índice, 24 de abril de 1997, núm. 30-9]; en cuanto a las enmiendas parciales, destacaban las presentadas por el Grupo Parlamentario Catalán ( $\mathrm{CiU}$ ), socios políticos del Gobierno en aquel momento, y el propio Grupo Popular, mayoritario en el Congreso y principal respaldo político del Gobierno, lo cual suponía la alteración sustancial del Proyecto aprobado por el Consejo de Ministros.

47 BOLETÍN OFICIAL DE LAS CORTES GENERALES. CONGRESO DE LOS DIPUTADOS (VI Legislatura), Serie A: Proyectos de Ley, 16 de septiembre de 1997, núm. 30-10, p. 59.

$48 \mathrm{Al}$ respecto, en concreto, vid. Juan Francisco SÁNCHEZ BARRILAO, "La liberalización de la televisión local... cit., pp. 131 a 133. Asimismo de interés, Ángel BADILLO y María de los Ángeles M ORENO : "La liberalización del audiovisual local: apunte sobre el caso de Castilla y León... cit., pp. 2 y 3; y "La política de comunicación del Partido Popular: el caso de la televisión local", Política y Sociedad, núm. 41, 2005, pp. 95 y ss.
} 
blico en favor de servicio de interés general, reduciéndose la intervención administrativa al respecto, de modo que la televisión local quedaba sujeta a un régimen de simple autorización administrativa, siendo competente para su otorgamiento las Comunidades Autónomas; además preveía la supresión de la prioridad en el otorgamiento de la concesión a los Municipios frente al resto de personas naturales y jurídicas; por otra parte, el número de autorizaciones pasaba a depender de la disponibilidad del espectro radioeléctrico, siendo competente la Administración General del Estado en la determinación de dicha disponibilidad y en la concesión de las frecuencias ( con lo que desaparecía el límite de una o, como máximo, dos concesiones por cada ámbito territorial de cobertura, pues el número de autorizaciones sólo vendría limitado por la disponibilidad del espectro radioeléctrico) ${ }^{49}$; y por último, se establecía un nuevo régimen transitorio para las emisoras de televisión local que estuvieran emitiendo con objeto de regular su situación, según el cual en el plazo de dos meses los titulares de tales emisoras deberían solicitar el otorgamiento de una autorización provisional de la Comunidad Autónoma correspondiente, previa inspección del Ministerio de Fomento de las instalaciones, y el titular de la emisora debía presentar una declaración comprometiéndose a solicitar una autorización definitiva ${ }^{50}$.

\footnotetext{
${ }^{49}$ También se prohibía la doble financiación de las televisiones locales gestionadas por los Municipios, no pudiéndose financiar simultáneamente mediante cánones o subvenciones y por ingresos publicitarios; se pretendía así evitar la doble financiación del servicio y la desleal competencia entre las televisiones locales municipales y las privadas.
}

${ }^{50}$ Aunque seguía sin establecerse un plazo máximo del período transitorio, sí se determinaba que, en caso de incumplimiento de los plazos para solicitar la inspección y la autorización provisional, o resolución del procedimiento de licitación sin que aquélla se transforme en definitiva, se obligaría al titular de la emisora a cesar en su actividad y a desmontar las instalaciones en un plazo de ocho meses; mientras tanto, al menos, la inspección previa por la Administración estatal hubiera garantizado cierto control público sobre tales emisiones televisivas, a la vez que efectivamente se hubiera acreditado que éstas existían antes del período transitorio (evitándose así situaciones en fraude de ley). Por otro lado, y según se ha adelantado, las enmiendas presentadas por los diversos Grupos Parlamentarios del Congreso alteraban notablemente el referido Proyecto y, en mayor o menor grado, el anterior régimen jurídico de la televisión local. Ciñéndonos a las enmiendas presentadas por los Grupos Catalán y Popular (núms. 58 a 73 y 74 a 91, respectivamente), destacaba la vuelta al servicio público (núms. 58, 75, 76 y 78) y la previsión nuevamente de un número máximo de concesiones, pero a determinar por las Comunidades Autónomas de acuerdo con las disponibilidades del espectro radioeléctrico según estableciera el Ministerio de Fomento (núms. 59 y 79). Por otra parte, se mantenía la valoración positiva de las personas naturales y jurídicas que sin ánimo de lucro se presentaran a concurso público de concesión administrativa ( núm. 85); y la estructura general del régimen transitorio anteriormente apuntado (núm. 91). 


\section{III.C.- LA TELEVISIÓN LOCAL TERRESTRE DIGITAL}

Sería al tiempo, con ocasión del proceso de implantación en España de la televisión digital, cuando la Ley 41/ 1995 se viera modificada a la luz de una serie de reformas parciales de la misma que, sin embargo, vendrían a alterar finalmente el régimen jurídico global de la televisión local. Tales reformas fueron introducidas por las referidas Leyes 22/ 1999, de 7 de junio (de Modificación de la Ley 25/ 1994, de 12 de julio, por la que se incorpora al Ordenamiento Jurídico Español la Directiva 89/552/ CEE, sobre la coordinación de disposiciones legales, reglamentarias y administrativas de los Estados miembros, relativas al ejercicio de actividades de radiodifusión televisiva) , 53/ 2002, de 30 de diciembre (de Medidas Fiscales, Administrativas y del Orden Social), 62/ 2003, de 30 de diciembre (de Medidas Fiscales, Administrativas y del Orden Social), y 10/ 2005, de 14 de junio (de Medidas U rgentes para el I mpulso de la Televisión Digital Terrestre, de Liberalización de la Televisión por Cable y de Fomento del Pluralismo).

Ahora, la televisión local terrestre se define tecnológicamente como digital, a la par que su ámbito territorial ya no se circunscribe al Municipio en sí: capitales de Provincia y de Comunidad Autónoma, Municipios “con población de derecho superior a 100.000 habitantes", organizaciones territoriales insulares, y Municipios colindantes "cuya población de derecho total sea superior a 25.000 habitantes o cuya cobertura incluya a todos los municipios en un radio de, al menos, 25 kilómetros" (arts. 1, y 3.2 y 3); así, en vez de hablar de una televisión local estrictamente municipal, quepa ahora referirse a una "televisión de proximidad" o comarcal al extenderse en general el ámbito territorial de la misma ${ }^{51}$.

En cuanto al número de concesiones, éste se amplia respecto a la originaria dicción del artículo 4 de la Ley 41/ 1995: en principio, corresponde al Gobierno la aprobación del Plan Técnico Nacional de la Televisión Digital Local, el cual ha de determinar "los canales múltiples necesarios y los ámbitos de cobertura" al respecto, atendiendo a las solicitudes presentadas por las Comunidades Autónomas y a las frecuencias disponibles, "que se determinarán respetando el derecho al acceso equitativo de todas ellas a los recursos de espectro, la compatibilidad radioeléctrica entre Comunidades adyacentes, así

\footnotetext{
${ }^{51}$ Sobre la proximidad frente a lo local en la televisión, vid. Emili PRADO, La televisión local entre el limbo regulatorio y la esperanza digital, Fundación Alternativa, Madrid, 2005, pp. 32 y ss.
} 
como las limitaciones derivadas de la coordinación radioeléctrica internacional" (art. 3.1); de otro lado, y conforme se ha adelantado, tales canales son "múltiples", "con capacidad para la difusión de, al menos, cuatro programas de televisión digital" (art. 3.2); y de acuerdo al ámbito territorial más arriba apuntado (art. 3.2 y 3, nuevamente). En consecuencia, el número de concesiones, de "canales múltiples" y de "programas" resulta inicialmente indeterminado, siendo el Plan quien lo delimite finalmente (art. 4).

Y respecto al tipo de gestión del nuevo servicio de la televisión digital, este será mixto, por cuanto que parte del mismo será a favor de las corporaciones municipales y los Cabildos y Consejos insulares, de un lado, y "por personas naturales o jurídicas, con o sin ánimo de lucro", de otro lado; pero en todo caso, previa obtención de la "correspondiente concesión" (art. 5). En principio, la nueva dicción de la Ley 41/ 1995 reserva a la gestión directa de los M unicipios un programa por demarcación, que en el caso de entidades colindantes será conjunta (a salvo de canales reservados a las Islas); no obstante, las Comunidades Autónomas pueden "reservar un segundo programa para ser gestionado de forma directa por los ayuntamientos" (art. 9.1). Mientras, el resto de los programas disponibles serán adjudicados por las Comunidades a particulares (arts. 9.2 y 13), pudiendo éstas "tener en cuenta como criterio positivo de valoración la experiencia demostrada en televisión local de proximidad por las compañías operadoras", la cual a su vez se "podrá acreditar, demostrando estar al amparo de la disposición transitoria primera de la Ley 41/ 1995" (art. 9.3).

Por último, y en relación al régimen transitorio $0^{52}$, la disposición transitoria primera de la Ley 41/ 1995 se ve ampliada, de modo que las emisoras que no obtengan la respectiva concesión, aun estando emitiendo antes del 1 de enero de 1995, "dejarán de emitir en un plazo de seis meses contado desde la resolución del concurso 0 , en su defecto, en un plazo de seis meses desde que se agote el plazo para resolver la adjudicación a la que se refiere la disposición transitoria segunda, sin que esta previsión suponga derecho a indemnización a los efectos del artículo 139.3 de la Ley 30/ 1992, de 26 de noviembre, de Ré-

52 Y sin perjuicio de otras reformas de la $L$ 41/ 1995, cuales son: art. 7.4 y 5, relativo a emisiones en cadena; art. 8, régimen de publicidad; art. 9.4, incorporación al tiempo de corporaciones locales a la gestión directa; art. 12, gestión del servicio por los Municipios; art. 14, duración de la prestación del servicio; art. 17, ejercicio de las competencias sancionadoras; y art. 21, características técnicas. 
gimen Jurídico de las Administraciones Públicas y del Procedimiento Administrativo Común. En el caso de las emisoras afectadas por concursos públicos fallados con anterioridad a la fecha de publicación de esta norma, los plazos para dejar de emitir contarán a partir de la mencionada fecha" (disp. trans. 1 a..4) 53 .

\section{III.D.- LA TELEVISIÓN DE PROXIMIDAD SIN ÁNIMO DE LUCRO}

Al margen de la Ley 41/ 1995 (incluidas sus ulteriores reformas, más arriba apuntadas), la disposición adicional decimoctava de la Ley 56/ 2007, de 28 de diciembre, de Medidas de Impulso de la Sociedad de la Información viene a regular una modalidad particular de televisión local en tanto que "televisión de proximidad sin ánimo de lucro"54; y ello, adelantamos, a fin de solventar la situación de canales locales de televisión de fuerte arraigo y presencia en sus

53 Disp. trans. 2a: “1. El plazo para la presentación de solicitudes por las Comunidades Autónomas, a que se refiere el artículo 3.1, comenzará el 1 de enero de 2003, y finalizará el 31 de marzo de dicho año. / 2. Dentro de los siete meses siguientes al plazo de finalización de presentación de solicitudes, el Gobierno aprobará el Plan Nacional de la Televisión Digital Local. / 3. El plazo del que dispondrán las Comunidades Autónomas para la decisión del número de programas reservados a los ayuntamientos y a las administraciones insulares y su correspondiente concesión, así como para la convocatoria de los concursos y adjudicación de las concesiones en gestión indirecta, expira el 31 de diciembre de 2005. / 4. Finalizado dicho plazo, las Comunidades Autónomas dispondrán de cinco meses para la convocatoria de los concursos y adjudicación de las concesiones. / 5. Los adjudicatarios de concesiones para la prestación de servicio público de televisión digital terrenal que hubieran efectuado emisiones al amparo de la disposición transitoria primera de la Ley 41/ 1995, podrán seguir utilizando tecnología analógica para la difusión de sus emisiones, siempre y cuando el ámbito territorial de las emisiones analógicas sea coincidente o esté incluido en el ámbito territorial correspondiente a la concesión digital adjudicada, durante dos años a contar desde el 1 de enero de 2006, siempre que así lo permitan las disponibilidades y la planificación del espectro establecida en los Planes Nacionales de Televisión, en el marco de la normativa reguladora del dominio público radioeléctrico. A dichos efectos, los concesionarios, presentarán ante la Secretaría de Estado de Telecomunicaciones y para la Sociedad de la Información las soluciones técnicas necesarias que permitan la emisión con tecnología analógica, sin que por ello se entiendan adquiridos derechos de uso del dominio público radioeléctrico distintos de los reconocidos en el correspondiente título concesional. Finalizado el plazo anteriormente señalado, aquéllas deberán emitir con tecnología digital y adaptarse a las previsiones contenidas en el Plan Técnico Nacional de la Televisión Digital Local. / 6. Se habilita al Gobierno para modificar el plazo a que se refiere el párrafo anterior a la vista del estado de desarrollo y penetración de la tecnología digital de difusión de televisión por ondas terrestres".

${ }^{54} \mathrm{Al}$ respecto, vid. Enrique LINDE PANIAGUA, José María VIDAL BERLTRÁN y Sara MEDINA GONZÁLEZ, Derecho audiovisual... cit., pp. 326 y 327. 
respectivas comunidades ( como por ejemplo las históricas "Tele Cardedeu" o "T ele-K"), y que, sin embargo, estaban quedando al margen de los concursos que se estaban ya resolviendo en diversas Comunidades Autónomas. En tal sentido, la Ley 56/ 2007 establece que el Ministerio de Industria, Turismo y Comercio (a través de la Secretaría de Estado de Telecomunicaciones y para la Sociedad de la Información, y mediante Resolución del Secretario de Estado) ha de planificar "frecuencias para la gestión indirecta del servicio de televisión local de proximidad por parte de entidades sin ánimo de lucro que se encontraran habilitadas para emitir al amparo" de la disposición transitoria primera de la Ley 41/ 1995, siempre que, eso sí, se disponga de frecuencias para ello (apartado 1o, primer párrafo); y a dichos efectos, ostentan "la consideración de servicios de difusión de televisión de proximidad aquellos sin finalidad comercial que, utilizando las frecuencias que en razón de su uso por servicios próximos no estén disponibles para servicios de difusión de televisión comercialmente viables, están dirigidos a comunidades en razón de un interés cultural, educativo, étnico o social" (apartado 1을 segundo párrafo) ${ }^{55}$. Por otra parte, el "canal de televisión difundido lo será siempre en abierto", debiendo consistir su programación "en contenidos originales vinculados con la zona y comunidad a la que vayan dirigidos" y sin poder incluir publicidad, ni tele venta, aunque cabe "el patrocinio de sus programas" (apartado 1으, tercer párrafo) ${ }^{56}$.

Al fin de desarrollar el régimen jurídico de la televisión de proximidad sin ánimo de lucro, la Disposición adicional decimoctava de la Ley 56/ 2007 delega en el Gobierno la aprobación del "reglamento general de prestación del servicio, con carácter de norma básica, y el reglamento técnico, en el que se establezca el procedimiento para la planificación de las frecuencias destinadas a servicios de difusión de televisión de proximidad, atendiendo entre otros extremos a las necesidades de cobertura, población y características propias de este servicio" (apartado 2 , , primer párrafo) ${ }^{57}$. Con todo, será aplicable lo dis-

${ }^{55}$ Adviértase ahora cómo aquí el concepto de proximidad cambia en relación a la L 41/ 1995 por cuanto que se refiere a "comunidades", y perdiendo así el sentido comarcal de aquélla.

${ }^{56}$ Además, la "entidad responsable del servicio de televisión local de proximidad no podrá ser titular directa o indirectamente de ninguna concesión de televisión de cualquier cobertura otorgada por la Administración que corresponda" (apartado 1o, párrafo cuarto).

57 Al momento de redacción de estas páginas, el Gobierno aún no ha aprobado tales reglamentos, si bien recientemente el Ministerio de Industria ha anunciado su próxima aprobación (17/ 6/ 2009). En cuanto al contenido de los mismos, la L 56/ 2007 prevé que el reglamento técnico ha de establecer "Ias condiciones técnicas que deberán reunir las frecuencias destinadas a es- 
puesto en la Ley 25/ 1994 (por la que se incorpora al ordenamiento jurídico español la Directiva 89/552/ CEE), relativas al ejercicio de actividades de radiodifusión, además de “lo previsto en los artículos 1, 2, 6, apartados 2 y 3 del artículo 9, 10, 11, 15, 18, 20, 21, 22 y apartado 4 de la disposición transitoria segunda de la Ley 41/ 1995", y "lo dispuesto en la Disposición Adicional Trigésima de la Ley 62/ 2003" (apartado 3).

En cuanto a la concesión de dichas televisiones, serán competentes las Comunidades Autónomas ${ }^{58}$, y se otorgarán por un plazo de cinco años aunque "podrán ser renovadas hasta en tres ocasiones, siempre que su actividad no perjudique la recepción de los servicios de difusión legalmente habilitados que coincidan total o parcialmente con su zona de cobertura" (apartado 50, primer párrafo) ${ }^{59}$. Por último, dichas concesiones obligan a la explotación directa del servicio, siendo intransferibles (apartado 5으, segundo párrafo).

\section{III.E.- PARADOJAS EN TORNO AL RÉGIMEN LEGAL DE LA TELEVISIÓN LOCAL TERRESTRE}

Conforme se ha adelantado, las referidas reformas de la Ley 41/ 1995 no se han limitado a modificar parcialmente el régimen jurídico de la televisión local terrestre, pues han terminado por dotarla de un régimen auténticamente diverso, a la par que paradójico. Decimos que el régimen es nuevo por cuanto que ahora la televisión local terrestre se define como digital, y no analógi-

tos servicios, la extensión máxima de la zona de servicio, la determinación concreta de las potencias de emisión, características y uso compartido del múltiplex asignado para la prestación del servicio y el procedimiento por el que las Comunidades Autónomas solicitarán la reserva de frecuencias para estos servicios, así como el procedimiento de asignación por parte de la Agencia Estatal de Radiocomunicaciones" (apartado 2을 segundo párrafo); mas, todo ello, sin que la planificación del espectro para la televisión de proximidad sea "prioritaria con respecto a otros servicios planificados o planificables" (apartado 2oㅡ, tercer párrafo).

58 “Las Comunidades Autónomas adjudicarán las correspondientes concesiones para la prestación de servicios de televisión de proximidad, de acuerdo con el reglamento general de prestación del servicio y su normativa" (apartado 4ํ).

59 “Las concesiones para la prestación de servicios de televisión de proximidad se extinguirán, además de por alguna de las causas generales previstas en el artículo 15 de la Ley 41/ 1995, de 22 de diciembre, de Televisión Local por Ondas Terrestres, por extinción de la personalidad jurídica de su titular y por su revocación" (apartado 60). Además, "serán causas de revocación de la concesión la utilización de las mismas para la difusión de servicios comerciales y la modificación de las condiciones de planificación del espectro radioeléctrico sin que exista una frecuencia alternativa" (apartado 7우). 
ca; y es que cada caracterización técnica de la televisión da lugar a una regulación jurídica diversa en tanto que dependiente de una u otra tecnología (según se advertía al comienzo de estas páginas). Además, mientras la tradicional televisión analógica resultaba relativamente sencilla a nivel técnico y baja en costes, lo que la hacía atractiva y asequible a nivel local tanto a particulares sin ánimo de lucro como a entidades públicas modestas, la tecnología digital dispara en costes la actividad televisiva, lo que la hace ahora bastante menos interesante a salvo de entidades privadas-mercantiles o públicas de cierta capacidad y posibilidades. A estos efectos, también, que se altere el ámbito territorial de la televisión local, por cuanto que ya no se limita al municipal en sentido estricto (según se ha señalado), al buscar circunscripciones territoriales con suficiente masa crítica que haga viable económicamente dicha televisión, y así que se hable de televisión de "proximidad", como hace la propia Ley (arts. 7.5 y 9.3 ).

Pero asimismo decimos que estamos ante un régimen paradójico por cuanto que al no darse una regulación enteramente nueva y coherente en su conjunto, la regulación vigente de la televisión local entra en contradicción interna al enfrentar principios propios de dos tipos de televisiones distintas. De esta forma, la referencia a sujetos particulares, que no privados (art. 13), o a la ausencia de ánimo de lucro como criterio a tener en cuenta por las Comunidades Autónomas a la hora de resolver los concursos públicos de concesiones a privados (art. 13.2), Ilama la atención cuando la televisión digital eleva los costes económicos haciéndola poco viable para sujetos particulares sin ánimo de lucro (conforme se ha apuntado arriba); en este sentido es más realista la Ley 41/ 1995 cuando, en su dicción vigente, habla de "compañías operadoras" (art. 9.3).

Pero las paradojas y perplejidades no terminan aquí, pues la L ey 41/ 1995, en un paso más, de un lado, en vez de fundamentar la liberalización (que a la postre supone) en el interés de los ciudadanos en el ejercicio de la libertad de expresión e información y en su derecho a recibir información plural (art. 20.1 a y d CE), lo hace en relación al de las Comunidades Autónomas (art. 3.1); claro que deberán ser éstas ahora las que hayan de canalizar tal interés de los ciudadanos a partir de sus propuestas al Estado respecto de la aprobación por él del Plan Técnico Nacional ( art. 3) , pero no hubiera estado de más que algún precepto de la Ley hiciera referencia expresa asimismo a dicho interés último de la ciudadanía. Además, y en todo caso, a la vista de los costes que supone la nueva televisión digital local ( y conforme venimos señalando), dicho interés se reconduce finalmente a la libertad de empresa, en su modalidad de televisión privada. 
De otro lado, y como auténtica perplejidad, está el que la Ley 41/ 1995 silencie el arraigo de aquellas televisiones que venían emitiendo a nivel local en relación a la resolución de los concursos públicos de las concesiones a privados por las Comunidades Autónomas cuando la propia Ley, en su dicción originaria, permitió su actividad respecto de las que vinieran emitiendo antes del 1 de enero de 1995 ( disp. trans. 1a). Cierto que las reformas prevén que las Comunidades puedan tener en cuenta la experiencia de sujetos privados en actividad televisiva local ("compañías operadoras") que vinieran emitiendo antes del 1 de enero de 1995 ( art. 9.3), pero ello sin concretar en relación al específico ámbito territorial en el que venían actuando aquéllos; y así que la emisión televisiva desde tal fecha en un concreto Municipio, su arraigo, no tenga que tenerse en cuenta más allá de la mera experiencia. Tal perplejidad, a su vez, resulta potenciada cuando, de una parte, la inactividad de los poderes públicos durante largo tiempo, por las razones que sean, han dado lugar a la prolongación durante años del régimen transitorio de la Ley 41/ 1995 ( y en tanto que televisión analógica); y de otra, la propia Ley ahora, tras su reforma, impide que aquéllos que vengan emitiendo antes del 1 de enero de 1995 y no hayan obtenido la respectiva concesión puedan obtener responsabilidad patrimonial alguna (disp. trans. $\left.1^{a} .4\right)^{60}$, lo que a su vez entronca con el principio de confianza legítima como límite de las potestades normativas ${ }^{61}$. Claro que dichas televisiones eran conscientes de la transitoriedad de su situación, de modo que tendrían que dejar de emitir en caso de que no obtuvieran las correspondientes concesiones ( y ello, en relación siempre a una televisión de tipo analógico con carácter inicial), pero otra cosa es que, finalmente, tal situación no haya sido efectivamente tenida en cuenta por la Ley a fin de permitir su consolidación jurídica (ya como televisión digital, y los consiguiente cambios técnicos e inversiones económicas en tal actividad televisiva).

Consecuencias de dichas paradojas son, finalmente, cómo el Plan Técnico Nacional de la Televisión Local Digital Local ha dejado fuera de las demarcaciones territoriales aprobadas (DD 439/ 2004 y 2268/ 2004) Municipios

60 En torno a las limitaciones del art. 139.3 L 30/ 1992 cfr., entre otros: Fernando GARRIDO FALLA; “Responsabilidad patrimonial del Estado legislador en la nueva Ley 30/ 1992 y en la Sentencia del Tribunal Supremo de 30 de noviembre", Revista Española de Derecho Administrativo, núm. 77, 1993, pp. 125 y ss.; y Tomás QUINTANA LÓ PEZ, "La responsabilidad del Estado legislador", Revista de Administración Pública, núm. 117, 1994, pp. 103 y ss.

${ }^{61}$ Acerca de dicho principio, de origen comunitario, vid. Íñigo SANZ RUBIALES, "EI principio de confianza legitima, limitador del poder normativo comunitario", Revista de Derecho Comunitario Europeo, núm. 7, 2000, pp. 91 y ss. 
con televisiones locales hasta ahora consolidadas, como es el caso, por ejemplo, de la localidad onubense de Nerva62. Y a la vista de los concursos celebrados en las diversas Comunidades Autónoma en relación a las concesiones de televisión digital local (al amparo de la anterior normativa), cómo, a nivel general, han quedado excluidos de dichos procesos no pocas televisiones locales con arraigo en los respectivos ámbitos municipales en los que venían emitiendo (en bastantes casos, por la propia negativa de éstas a participar en tales concursos ante los costes que la televisión digital supone y la falta de medios con que afrontarlos), mientras que se han extendido grupos mediáticos privados nacionales y regionales de televisión local, con un grado significativo de concentración de la propiedad (horizontal y/ o multimedia) al respecto. Así, cabe apreciar dos grandes categorías de adjudicatarios: el más importante, consistente en fuertes grupos de comunicación empresarial a nivel nacional y regional (con mayor capacidad para hacer frente a los retos técnicos y económicos que conlleva la televisión digital), que intentan llegar a todos los ámbitos de cobertura posibles; y otro mucho más reducido, los concesionarios únicos sin respaldo empresarial, los cuales han pasado a ocupar una posición más limitada, en especial frente a la presencia que ostentaban en la etapa analógica anterior ${ }^{63}$. Con ello, y contradictoriamente a la liberalización que vendría a potenciar la televisión local digital conforme a la Ley 41/ 1995 en su dicción vigente, se observa una reducción del pluralismo televisivo local, si no a nivel de cada una de las demarcaciones territoriales, sí que desde una perspectiva general ( ya sea estatal, o autonómica).

Ciertamente, lo anterior, se ha intentado resolver al tiempo mediante la comentada disposición adicional decimoctava de la Ley 56/2007, conforme a la cual se prevé una modalidad particular de la televisión local en tanto que "televisión de proximidad sin ánimo de lucro", mas sin integrarse en la regulación misma de la Ley 41/ 1995, lo que no viene sino a aumentar todavía más las paradojas anteriormente referidas. Así, dado que televisión local específi-

62 Cfr. Carmen del Rocío MONEDERO MORALES, "El futuro de la televisión local en Andalucía", en www.hapaxmedia.net/ ibercom/ pdf/ MonederoMoralesCarmen.pdf (19/03/ 09) , p. 3.

${ }^{63}$ Cfr. María COROMINAS PIU LATS, Montse BONET BAGANT, Isabel FERNÁNDEZ ALON SO, Josep Àngel GUIM ERÀ I O RTS, Julián SANM ARTÍN NAVARRO y José Joaquín BLASCO GIL, "Televisión digital terrestre local (TDT-L) en España: los concesionarios privados", Zer. Revista de Estudios de Comunicación, núm. 12/ 22, 2007, pp. 69 y ss. Se ha de advertir que en este estudio únicamente de analizan los concursos celebrados hasta diciembre de 2006, con lo que queda fuera del mismo el llevado a cabo en Andalucía (del que más adelante se dará debida cuenta en estas páginas). 
ca, y aunque aplicable buena parte de la Ley 41/ 1995, la definición que del "sin ánimo de lucro" hace la Ley 56/ 2007 no es extensible al que con carácter general plantea la 41/ 1995, a modo de criterio preferente en la concesión (aunque pueda servir de criterio orientador). Pero es más, pues tampoco cabe admitir que la Ley 56/ 2007 prevea una auténtica modalidad abstracta de televisión de proximidad frente a la más genérica local, ya que resulta limitada a aquellas televisiones que vienen emitiendo al amparo de la disposición transitoria primera de la Ley 41/ 1995 (recuérdese, desde antes del 1 de enero de 1995), y siempre que se disponga de frecuencias para ello (apartado 1ㅇ, primer párrafo); con ello, como mucho, lo que se permite es el mantenimiento de canales televisivos que sin ánimo de lucro vienen emitiendo y no han conseguido la concesión correspondiente para seguir emitiendo, pero no la aparición de canales nuevos, de modo que parece más lógico entender tal regulación como parte del régimen transitorio de la Ley 41/ $1995^{64}$.

\section{LA TELEVISIÓN LOCAL EN ANDALUCÍA}

Cuestión previa al análisis del régimen jurídico de la televisión local en Andalucía está la constatación fáctica de cómo tal actividad se remonta en ésta a comienzos de la década de los ochenta del Siglo pasado, y consolidándose desde entonces una televisión a nivel local y en analógico tanto en manos de los propios Municipios como de particulares, y sin cobertura jurídica alguna hasta la referida Ley 41/ 1995 (dispos. transit. 1ㄹ) ${ }^{65}$. Ello, sin duda, ha influido en la regulación que de la televisión local ha ofrecido la Junta de Andalucía, conforme se viene seguidamente a señalar; pero otra cosa es cómo repercuta en la gestión por la Junta del apagón de la televisión local analógica ( según se comenta al final de estas páginas).

${ }^{64} \mathrm{Al}$ que efectivamente modifica, al permitir que televisiones locales que venían emitiendo de acuerdo a la misma, y crean cumplir el régimen jurídico previsto por la L 56/ 2007, puedan seguir emitiendo aun sin haber obtenido la oportuna concesión digital hasta tanto no se termine por regular reglamentariamente la televisión de proximidad sin ánimo de lucro y las CCAA no hayan resuelto las correspondientes concesiones.

65 En 2006 eran más de un centenar las televisiones locales que emitían en Andalucía, de las cuales un $32 \%$ eran públicas (asociadas en torno a EMA-RTV, con 20 Ayuntamientos), y el resto privadas (destacando las 116 asociadas a ACUTEL); cfr. Nuevamente Carmen del Rocío MONEDERO MORALES, "El futuro de la televisión local en Andalucía... cit., p. 2. También de interés, Juan Carlos RODRÍGUEZ CENTENO, "La televisión local pública en Andalucía. Publicidad y otras formas de financiación", en www.unav.es/fcom/ cicom/ PDF\%20Comunicaciones/ grupo\%202/ juancarlos\%20rodriguez.pdf, pp. 2 a 5. 


\section{IV.A.- EL RÉGIMEN TRANSITORIO}

Bajo el marco competencial definido por los artículos 149.1 .21 y 27 de la Constitución y 16 de Ley O rgánica 6/ 1981, de 30 de diciembre (anterior EA), junto a la legislación básica estatal al respecto de la televisión local (además de la L 41/ 1995, las referidas LL 31/ 1987 y 11/ 1998), la Comunidad Autónoma de Andalucía acabaría aprobando (y aún a la espera de la ordenación estatal del espacio radioeléctrico) el Decreto 414/2000, de 7 de noviembre, por el que se regulaba el régimen jurídico de las televisiones locales por ondas terrestres, y en especial el procedimiento y otorgamiento de las concesiones ${ }^{66}$. De acuerdo a éste, tal televisión se definiría así en Andalucía, y en aquel momento (siempre, conforme a la L 41/ 1995 en su dicción originaria), por su publicatio (arts. 1 y 2.2), sin contraprestación (art. 2.1), su tecnología analógica (art. 2.1, in fine), y su ámbito municipal (arts. 2.1 y 3), sin perjuicio de que su gestión se concibiera a favor de los respectivos Municipios y sujetos privados, en su caso, mediante la correspondiente y previa concesión administrativa (art. 2.2): en principio, una única concesión por ámbito municipal y a favor de su gestión por el propio Municipio, y en caso de que éste rehusara entonces ya de gestión privada ( por acuerdo de la Junta); y pudiéndose otorgar una segunda concesión cuando no resultare incompatible con las disponibilidades del espectro radioeléctrico y atendiendo a la viabilidad económica de las emisoras, siendo en tal caso la segunda concesión privada (art. 4) ${ }^{67}$.

A continuación el Decreto pasaba a regular, en detalle: la prestación del servicio de televisión local terrestre, en particular los principios inspiradores del mismo (art. 5) ${ }^{68}$ y la prohibición de emisiones en cadena, sin perjuicio de su autori-

66 En relación a otras Comunidades Autónomas, y en tal momento, sólo otras dos aprobaron una regulación de la televisión local; eran los casos de Cataluña, con el D 320/ 1996 (de 1 de octubre), y Castilla-La Mancha con el D 54/ 2000 (de 21 de marzo).

${ }^{67}$ Nótese cómo el D 414/ 2000 ya no habla de gestión "particular", sino "privada", además de atender a criterios de viabilidad económica.

68 Entre otros: objetividad, veracidad e imparcialidad de las informaciones; separación entre informaciones y opiniones, identificación de quienes sustentan estas últimas y su libre expresión con los límites previstos en el art. 20.4 CE; respeto al pluralismo político, religioso, social y cultural; respeto al honor, a la intimidad personal y familiar, a la propia imagen y a todos los derechos y libertades reconocidos por la CE; protección de la juventud y de la infancia (conforme Cap. IV L 25/ 1994; respeto al derecho de igualdad; fomento y defensa de la cultura e intereses locales, así como la promoción de la convivencia, impulsando la participación de grupos sociales del corres- 
zación excepcional por la Junta en caso de Municipios limítrofes (art. 6); la gestión del servicio [Cap. II, en especial: el régimen de las concesiones (art. 7); la gestión municipal del servicio (art. 8); y la gestión privada del mismo (art. 9) ]; el procedimiento y otorgamiento de las concesiones [Cap. III: procedimiento de concesión, a nivel general (art. 10), y: fase de solicitud (art. 11); reserva de frecuencia (art. 12); fase de adjudicación (art. 13); adjudicación provisional (art. 14); proyecto técnico y ejecución (art. 16); y adjudicación definitiva (art. 17) ], con particular atención a los criterios de adjudicación de los concursos a particulares, y entre tales, nuevamente, la carencia de ánimo de lucro (art. 15) ${ }^{69}$; la programación [Cap. IV: tiempo mínimo de emisión, de cuatro horas diarias (art. 18); mínimo de producción propia del $50 \%$ (art. 19) ${ }^{70}$; protección del menor (art. 20) ; y régimen jurídico de la publicidad (art. 21) ]; la explotación de las ca-

pondiente ámbito territorial; fomento de la conciencia de identidad andaluza a través de la difusión de valores culturales y lingüísticos del pueblo andaluz en toda su riqueza y variedad; protección de la dignidad y de los derechos de la mujer y promoción efectiva de la igualdad sin distinción de sexo; y fomento de comportamientos tendentes a la correcta utilización de los recursos naturales y a la preservación del medio ambiente.

${ }^{69}$ Criterios de adjudicación (provisional): “El Consejo de Gobierno, al efecto del otorgamiento de la adjudicación provisional a personas naturales y jurídicas, ponderará el grado de concurrencia conjunta en el solicitante de los siguientes aspectos: a) El interés cultural o educativo del proyecto, valorando esencialmente el fomento de las diferentes manifestaciones de la cultura local y andaluza. b) La promoción de la diversidad etnográfica y social dentro del ámbito territorial de cobertura, especialmente a través de la participación de los grupos sociales más significativos. c) La creación de emisoras que realicen su programación en municipios con población dispersa en núcleos urbanos aislados, cuando su puesta en marcha suponga un factor de integración territorial y de conocimiento de los servicios públicos. d) La viabilidad del proyecto y las garantías de continuidad en la prestación del servicio. e) La capacidad profesional y experiencia de los solicitantes, en aras al mayor cumplimiento de los principios inspiradores establecidos en el artículo 5 de este Decreto. f) El compromiso de realizar una programación que sobrepase los mínimos establecidos en los artículos 18 y 19 de este Decreto. g) La prestación correcta del servicio, cuando se trate de solicitantes que han sido concesionarios anteriormente de un medio de comunicación social. Se entenderá correcta la prestación del servicio cuando el concesionario haya dado cumplimiento a los compromisos concesionales y no haya sido sancionado por alteraciones de los parámetros técnicos asignados. h) Compromiso de desarrollar programas de formación ocupacional y de fomento de la creación de empleo. i) Compromiso de tener su domicilio social y su centro principal de actividad en el ámbito territorial de la emisora objeto de la concesión. j) La carencia de ánimo lucrativo en los fines de la entidad solicitante. k) Compromiso de mantener en su plantilla el mayor número posible de discapacitados, por encima del $2 \%$ previsto en el Real Decreto Legislativo $2 / 2000$ [... ]. I) Otros que, a la vista de la documentación presentada, sean considerados especialmente relevantes".

70 “[ ... ] si bien se considerará como producción propia hasta un 50\% de la programación coproducida o la realizada por terceros en Andalucía". 
denas [ Cap. V: condiciones y obligaciones de explotación (art. 22); duración de la concesión (art. 23); y extinción de la concesión (art. 24) ]; y el régimen sancionador y de inspección [Cap. VI: infracciones y sanciones (art. 25); competencia sancionadora (art. 26); y facultad inspectora (art. 27) ].

De otra parte, el Decreto 414/ 2000 regulaba de manera transitoria la actividad de las televisiones existentes con anterioridad al uno de enero de 1995 (al amparo de la disp. trans. 1a L 41/ 1995), obligando a los Municipios y personas titulares de las mismas a "participar en el primer proceso que se convoque en aplicación" de dicho Decreto (disp. trans. única, 1) 71 ; y al tiempo, advirtiendo que aquéllos que no obtuvieran concesión en dicha convocatoria tendrían "que cesar necesariamente sus emisiones en el plazo de ocho meses a partir de la notificación de la Resolución denegatoria" (disp. trans. única, 2) ${ }^{72}$. Ahora bien, la efectividad del Decreto 414/ 2000 en su conjunto, y la adjudicación de las concesiones en particular, quedaría fatalmente condicionada a la previa realización por el Estado de una reserva y asignación de frecuencias que no terminaba de hacer en aquel momento; y es que se había iniciado ya el proceso de transformación normativa de la televisión local analógica a la digital ( $L$ 53/ 2002), quedando en suspenso la referida adjudicación, mientras las televisiones locales analógicas seguían funcionando sin la correspondiente concesión y bajo una situación de interinidad jurídica que se prologaba ya desde 1995. Es por ello por lo que la Junta de Andalucía procedería a regular con mayor detalle el marco jurídico transitorio para las emisoras de televisión local por ondas terrestres mediante un nuevo Decreto, el 365/2003, de 30 de diciembre: en particular, mediante el otorgamiento de una autorización administrativa general expresa, de carácter transitorio (durante el proceso de transición de los servicios de televisión analógica hasta la definitiva implantación de la tecnología digital), a las emisoras que cumplieran determinados requisitos, a fin de ofrecer cierto reconocimiento institucional a las mismas por la Junta.

\footnotetext{
71 Orden de 6 de febrero de 2001, de la Consejería de la Presidencia, de convocatoria para la solicitud de concesiones de televisiones locales por ondas terrestres en Andalucía; al respecto de la misma, sólo pudo realizarse la primera fase de solicitud, quedando pendiente la de adjudicación a las reservas de frecuencias que habría de haber realizado el Ministerio de Ciencia y Tecnología.

72 El D 414/ 2000 sería a su vez reformado en dos ocasiones, por el D 27/ 2001, de 13 de febrero (arts. 6.2 y 3, 9.4 y 22.d D. 414/ 2000), y el D 114/ 2001, de 8 de mayo (nuevamente art. 6.2), hasta su ulterior derogación: tácita y parcial, por el D 365/2003, de 30 de diciembre (disp. der. ); y expresa y definitiva, por el D 1/ 2006, de 10 de enero (disp. der. única).
} 
A dichos efectos, el Decreto 365/ 2003 vendría a detallar el régimen jurídico transitorio del servicio público de televisión local por ondas terrestres que emitían, aún, en Andalucía al amparo de la disposición transitoria primera de la Ley 41/ 1995 (art. 1.1). Y ello, en tanto que: no se produjese por el Estado la planificación y la reserva de las frecuencias para la prestación de tal servicio, y la Junta no resolviese los correspondientes procesos de adjudicación de concesiones (art. 1.2); o bien (y en el caso de que antes de dicha resolución), se produjera la transición definitiva de la tecnología analógica a la digital (y por tanto la sustitución de la primera por la segunda), y una vez resueltos los concursos de televisión digital terrestre que se habrían de convocar (art. 1.3). En cuanto al referido régimen transitorio, el Decreto establecía: Ios principios que inspiraban la prestación del servicio de televisión local por ondas terrestres ( art. 2) ${ }^{73}$; las condiciones de gestión del servicio tanto por los propios Municipios (art. 4), como por personas privadas (art. 5); las obligaciones a las que quedaban sujetas las personas titulares de las televisiones locales (Cap. II) ${ }^{74}$; en especial, la autorización administrativa general de la actividad televisiva local (en virtud de la cual se reconocería el derecho a continuar la prestación del servicio de televisión local), así como un censo al respecto (Cap. III) ${ }^{75}$; y

73 En principio, en sintonía con lo establecido en el anterior art. 5 del D 414/ 2000, si bien extendiéndose en dos nuevos puntos: "la separación perceptible de la programación y de la publicidad, de manera que resulte inequívoco el carácter publicitario de los mensajes" (art. $2.11 \mathrm{D}$ $365 / 2003)$; y "la potenciación de la industria audiovisual de contenidos presente en el mismo territorio de cobertura" (art. 2.12 D 365/ 2003).

${ }^{74}$ Además de los principios del art. 2, se establecen las siguientes obligaciones (art. 6) : explotación directa del servicio; respeto de las condiciones en base a las cuales se haya obtenido la autorización administrativa general; facilitar las comprobaciones e inspecciones que deban llevarse a cabo para la verificación del cumplimiento de lo dispuesto en el D 365/2003; notificar los cambios que se realicen en la designación del director o responsable de la emisora, así como de actos o negocios que comporten la transmisión, disposición o gravamen de las acciones o participaciones de la sociedad titular; cumplir las prescripciones que se establecen en los arts. 7 y 8 del D 365/ 2003 sobre Programación y Publicidad; y conservar todas las emisiones, incluidas las de publicidad y televenta, realizadas durante los últimos tres meses (a los efectos de comprobación e inspección). Asimismo, las televisiones locales se encuentran sujetas a la normativa aprobada por la Junta referente a la inspección de infraestructuras de telecomunicación, así como a la regulación sobre la utilización de la radio y la televisión en caso de emergencias, y al resto de normas que les resulten aplicables ( disp, adic. $2^{2}$ ) .

75 Alcance jurídico de la autorización administrativa general (art. 9.1); censo, de mero carácter declarativo, de los titulares de las autorizaciones concedidas, así como de parámetros técnicos (art. 9.2); órgano competente en el otorgamiento de la referida autorización (art. 10), y procedimiento de otorgamiento de la misma (art. 11: instancia de parte, plazo y documentación a pre- 
la inspección y sanciones (Cap. IV) ${ }^{76}$. Con ello, la Junta de Andalucía pretendía, en el marco de sus competencias, ofrecer una regulación transitoria de mayor detalle en relación a la actividad televisiva local, a fin de salvaguardar tanto el interés público, como la seguridad jurídica y el propio amparo legal de los operadores de este sector.

Pero en un paso más, el Decreto 365/ 2003 preveía que aquellas personas físicas o jurídicas titulares de televisiones locales que se encontraran emitiendo en la fecha de entrada en vigor del mismo ( 6 de enero de 2004, conforme disp. final 2a), y no se hallaran incluidas en el régimen transitorio de la Ley 41/ 1995 (se recuerda, las que hubieran comenzado a emitir tras el 1 de enero de 1995), pudieran solicitar a la Junta (Dirección General de Comunicación Social) su incorporación en el referido censo, lo que conllevaba, de manera implícita, el cumplimiento de las obligaciones previstas en aquél (disp, adic. 1…1) ${ }^{77}$. E incluso, que en los ulteriores procesos de adjudicación para el otorgamiento de las concesiones de televisión local por ondas terrestres se hubiera de valorar, en su caso ( y en los términos que estableciera la normativa correspondiente), el haber obtenido la autorización administrativa general, así como hallarse en el censo (disp. trans. única). Ambas previsiones suponían, sin embargo, ir más allá del régimen transitorio anteriormente apuntado, por cuanto que, y en al gún grado, la Junta de Andalucía: de una parte, pasaba a amparar una actividad televisiva que estaba fuera del régimen transitorio previsto por la Ley 41/ 1995; y de otro, planteaba una cierta previsión de tener en cuenta el arraigo de los operadores televisivos locales con ocasión de las ulteriores y definitivas adjudicaciones de concesiones por ella.

IV.B.- EL DECRETO 1/ 2006 POR EL QUE SE REGULA EL RÉGIMEN JURÍDICO DE LAS TELEVISIONES LOCALES POR ONDAS TERRESTRES EN ANDALUCÍA

La comentada reforma de la Ley 41/ 1995 por las Leyes 22/ 1999, 53/ 2002, $62 / 2003$ y 10/ 2005, conforme a la cual la televisión local pasa a definirse como

sentar, y propuesta, resolución y notificación); y eficacia y extinción de la autorización administrativa general (art. 12: en particular respecto al estricto cumplimiento del D 363/ 2003 y el resto de normativa aplicable, y la resolución de los correspondientes procesos de adjudicación de las concesiones). También, téngase en cuenta disp. adic. 1ạ.3 y 3ạ.

76 Inspección (art. 13); régimen sancionador (art. 14); y competencia sancionadora (art. 15).

77 “A la solicitud se acompañará la documentación establecida en el artículo 11.2.2, a excepción de la prevista en el apartado h) que habrá de ser sustituida por la documentación acreditativa de que la televisión local se encuentra emitiendo por ondas terrestres en la fecha de entrada en vigor del presente Decreto" (disp, adic. 1ạ.2). 
digital, a tener carácter supramunicipal y a preverse de canales múltiples (además de la aprobación del Plan Técnico Nacional por el RD 439/ 2004, y su modificación por el RD 2268/2004, y del Plan Técnico Nacional de Televisión Digital Terrestre -RD 944/ 2005- y del Reglamento General de Prestación del Servicio de Televisión Digital -RD 945/ 2005), justificó la necesidad por la Junta de Andalucía de aprobar, a su vez, una nueva normativa al respecto: ésta sería el Decreto $1 / 2006$, de 10 de enero, por el que se regula el régimen jurídico de las televisiones locales por ondas terrestres en Andalucía, sustituyendo al comentado Decreto 414/ 2000 (y sus modificaciones), al que deroga junto al Decreto 365/ 2003 (disp. derog. única); dicho Decreto 1/ 2006 consta de cinco CapítuIos, relativos a "disposiciones generales" (Cap. I), "gestión del servicio" (Cap. II), "programación y publicidad" (Cap. III), "concesiones y los procedimientos para su otorgamiento" (Cap. IV) e "inspección y régimen sancionador" (Cap. V). En cuanto a los aspectos esenciales de éste (a los efectos de estas páginas), y a la luz de la vigente Ley 41/ 1995, destacan los siguientes.

Respecto al ámbito territorial de cobertura de cada canal múltiple de televisión digital local, el Decreto 1/ 2006 se remite a los términos municipales "que integran cada una de las demarcaciones previstas en el Plan técnico nacional de la televisión digital local" correspondientes a la Comunidad Autónoma de Andalucía (art. 3.1 y anexo I) ${ }^{78}$; no obstante, podrá solicitarse la extensión del servicio a otras localidades (art. 3.3). Y en relación al número de programas, "cada canal múltiple se destinará a la difusión de al menos cuatro programas de televisión digital", sin perjuicio de que pueda "reservarse hasta un 20 por ciento de la capacidad de transmisión digital del canal múltiple para la prestación de los servicios adicionales de datos" (arts. 4.1 D 1/ 2006, y 5 y 6 RD 439/2004) y quepa fijarse "un número mayor de programas de televisión digital en cualquiera de los canales múltiples de cobertura local, siempre que se respeten los requerimientos técnicos y quede garantizada una calidad de servicio satisfactoria" (arts. 4.2 D 1/ 2006 y 5.2 RD 439/ 2004). Y en cuanto a la gestión de los mismos, se ha de distinguir la de los programas y la del propio canal múltiple.

En relación a los primeros, y conforme a la vigente Ley 41/ 1995, el Decreto 1/ 2006 prevé su gestión directa por los Municipios, así como por personas naturales o jurídicas, con o sin ánimo de lucro, y previa obtención en todo caso de la correspondiente concesión otorgada por la Junta de Andalucía

\footnotetext{
${ }^{78}$ Además, "en el interior de la zona de servicio deberá asegurarse la captación de las señales de televisión digital local con calidad satisfactoria en condiciones de recepción fija" (art. 3.2).
} 
( art. 7.1) ${ }^{79}$. A tales efectos, los Municipios incluidos dentro de una misma demarcación pueden acordar la solicitud de la gestión directa de un programa (art. 7.2) ${ }^{80}$, previo acuerdo de los respectivos Plenos ( art. 7.3); y en el caso de que sean varios los M unicipios solicitantes en una misma demarcación, la gestión será atribuida conjuntamente (arts. 7.4 y 8$)^{81}$. Con todo, los Municipios deben solicitar la oportuna concesión, en su modalidad "de gestión directa", participando así en los correspondientes procedimientos de adjudicación de concesiones que se convoquen (art. 8.1), y una vez acordada dicha concesión la gestión deberá respetar el principio de pluralismo (art. 8.5). De otro lado, en cuanto a la gestión privada del servicio televisivo local, las personas naturales o jurídicas quedan sujetas a determinadas condiciones y límites referidos a nacionalidad (española o de otro Estado miembro de la Unión Europea), capacidad para contratar con la Administración y accionariado (art. 9.1). Y respecto a la gestión del canal múltiple, ésta es colectiva, correspondiendo a un órgano interno en el que han de estar "representadas todas las personas concesionarias de programas del mismo, de forma proporcional al número de programas de que son adjudicatarios" (art. 10.1) 82.

${ }^{79}$ Respecto a las concesiones, arts. 19 y ss.

80 Excepcionalmente, cabe la posibilidad de que los Municipios integrados en una misma demarcación soliciten a la Comunidad la ampliación a dos del número de programas (art. 7.2).

81 En tal supuesto, los Municipios han de constituir una sociedad mercantil local con capital exclusivamente público y participada por los mismos (cuyo objeto social sea la gestión directa del servicio), o adoptar cualquier otra forma de gestión directa prevista en el art. 85.2.A L 7/ 1985. Además, la entidad gestora que se constituya debe atender, en cuanto a la participación de cada Municipio, a criterios de población. En caso de que no se logre un acuerdo al respecto por todos los Municipios, cabe que la gestión se encomiende a una entidad gestora integrada por aquéllos que sumen una población censada que represente más de las tres quintas partes del total de la demarcación. En caso de no alcanzarse. Por último, en los estatutos de dichas entidades deberá establecerse la forma de realización de la gestión conjunta del servicio, los principios básicos de su gestión, y la posible incorporación o baja posterior de cualquiera de los Municipios incluidos en la zona de servicio del canal múltiple (art. 8.1). De otra parte, en las demarcaciones en las que se hayan previsto dos canales múltiples, podrá destinarse un programa por cada canal para su gestión pública; a estos efectos, los Municipios podrán decidir agruparse para la gestión conjunta de cada uno de ellos, y en caso de no alcanzarse el acuerdo entre los Municipios, la atribución de los programas se realizará atendiendo a criterios de población, atribuyéndose la gestión de uno de los programas al Municipio más poblado, y asignándose el otro u otros programas al resto de Municipios (art. 8.3).

82 Para las funciones de dicho órgano, vid. art. 10.2; y en relación a su organización, art. 10. 4. De otra parte, acerca de la gestión técnica del canal múltiple, art. 12.1; sobre su registro, art. 12.2; y en cuanto a las funciones de tal gestión técnica, art. 13. Y por último, acerca de los requisitos de los gestores y el modo de realizar la misma, art. 40. 
Por otra parte, y para una cabal comprensión del alcance sustantivo que del servicio de la televisión local hace el Decreto 1/ 2006 en la Comunidad Autónoma andaluza, se ha de atender a:

Los principios inspiradores del servicio de televisión local en Andalucía, lo cuales, si bien (y en buena medida) responden a los declarados en los Decretos anteriores, presentan al guna novedad ${ }^{83}$, destacan do (a los efectos de estas páginas) "el respeto a los derechos que los espectadores tienen reconocidos por la normativa vigente, en su condición de usuarios" (art. 6.n), mas silenciando su condición de titulares del derecho fundamental a recibir información (art. 20.1.d CE).

La obligación de los titulares de las concesiones "a emitir programas televisivos originales durante un mínimo de cuatro horas diarias y treinta y dos semanales, comprendidas íntegramente en las franjas horarias que van desde las 13 a las 16 horas y desde las 20 a las 24 horas" (art. 14.2), sin que se considere como tal las imágenes fijas, la publicidad, la tele venta o los juegos y concursos promocionales (art. 14.3), ni tampoco "la mera reemisión de programas televisivos cuya difusión se haya realizado o se esté realizando por cualquier otra emisora de televisión" (art. 14.4) ${ }^{84}$. Pero a su vez, "veintiséis de las treinta y dos horas semanales mínimas dedicadas a la programación original [... ] serán de producción propia y referidas a contenidos relacionados con el ámbito territorial de cobertura de la demarcación en la cual se es concesionario" (art. 14.7) ${ }^{85}$. Ello, sin duda, supone un importante coste mínimo de producción interna de los programas (en tecnología digital), lo que limita las posibilidades de particulares sin ánimo de lucro, y que se añade a los referidos en relación a la gestión colectiva del canal múltiple, más arriba comentada.

La valoración preferente, como criterio de adjudicación de las concesiones ( art. 34.1), de: los contenidos de la programación; la viabilidad técnica del proyecto; la viabilidad económica del proyecto (lo que entra en conexión con

${ }^{83}$ Como la "protección de los derechos de la tercera edad, las personas con discapacidad, los inmigrantes y otros colectivos necesitados de una mayor protección" (art. 6.f) y "facilitar la accesibilidad a las personas con discapacidad auditiva o visual" (art. 6.0).

${ }^{84}$ Además, al respecto, atiéndase al art. 14.5 y 6 .

85 “[... ] podrá entenderse por producción propia aquélla coproducida con terceros en Andalucía, con el límite, para el supuesto de concesiones privadas, de trece horas de las veintiséis requeridas" (art. 14.7, in fine). 
los costes que venimos advirtiendo); las aportaciones a la extensión de la televisión digital; las aportaciones a la economía andaluza (lo que potencia todavía más su dimensión económica); y la experiencia demostrada en televisión local de proximidad, mas guardando silencio a su arraigo en la demarcación ( con lo que tal experiencia puede referirse tanto a otras demarcaciones andaluza, como de otras Comunidades) a pesar de que al amparo del anterior Decreto 365/ 2003 debiera valorarse el haber obtenido la autorización administrativa general, así como hallarse en el censo (otra vez, disp. trans. única). Por último se ha de valorar positivamente a "Ias entidades sin ánimo de lucro" (art. 34.2), lo que sin embargo resulta difícilmente asumible a la vista de los costes económicos que supone la nueva televisión local digital, en especial frente a la anterior analógica, además de los criterios económicos señalados.

Y la consideración como infracción muy grave de emitir careciendo de la correspondiente concesión administrativa, dando lugar a la "aplicación del oportuno régimen sancionador, pudiendo adoptarse como medida de carácter provisional el cierre de la actividad", e implicando tal infracción "una multa económica entre 60.000 y 1.000 .000 de euros" (art. 45.1). Ello, además, entra en conexión con la disposición transitoria única del Decreto $1 / 2006$, conforme a la cual ( y al amparo de la disp. trans. 1a L 41/ 1995), las emisoras de televisión local que estuvieran emitiendo con anterioridad al uno de enero de 1995, deben obtener "para continuar con su actividad la correspondiente concesión", de modo que "en caso de no obtenerse dicha concesión tales emisoras dejarán de emitir en un plazo de 6 meses a contar desde la resolución del concurso".

\section{IV.C.- EL NUEVO MARCO ESTATUTARIO}

Según lo señalado en el apartado II.C, las últimas reformas de los Estatutos de Autonomía llevadas a cabo han supuesto un nuevo marco estatutario de la actividad televisiva en cuanto que, de un lado, conllevan un mayor grado de especificación de los perfiles competenciales al respecto, de otro, incluyen derechos y principios relativos a dicha actividad, e incluso, en algún caso, dedican un Título específico a los medios de comunicación (y por tanto a la propia televisión). Así acontece precisamente con ocasión de la reforma del Estatuto de Autonomía de Andalucía a la vista de la Ley Orgánica 2/ 2007, de 19 de marzo, de manera que el anterior marco normativo andaluz relativo a la televisión local habrá de adecuarse al respecto. En este sentido destaca, a nivel competencial: la competencia exclusiva de la Comunidad sobre la organización de la prestación de los servicios públicos de comunicación audiovisual de ámbito local, sin perjuicio del respeto de la garantía de la autonomía local 
(art. 69.1 EA); el desarrollo legislativo y la ejecución por la Comunidad sobre competencias de medios de comunicación social, lo que incluye, claro está, los de ámbito local (art. 69.3 EA); y la competencia compartida entre el Estado y la Comunidad sobre ordenación y regulación y el control de los servicios de comunicación audiovisual que utilicen cualquiera de los soportes y tecnologías disponibles dirigidos al público de Andalucía, así como sobre las ofertas de comunicación audiovisual si se distribuyen en el territorio de Andalucía (art. 69.4 EA) ${ }^{86}$.

De otra parte, y en relación a los nuevos derechos y principios rectores establecidos por el nuevo Estatuto andaluz, está87, de manera específica ${ }^{88}$, el derecho a acceder y usar las nuevas tecnologías y a participar activa-

\footnotetext{
${ }^{86}$ Sobre el mismo, vid. José María CASTRO PASCUAL, "Artículo 69", en AAVV Comentarios al Estatu to de Autonomía para Andalucía (L ey Orgánica 2/2007, de 19 de marzo), Mónica O rtiz Sánchez e I gnacio Carrasco López (coords.), Instituto Andaluz de Administración Pública, Sevilla, 2008, pp.
} 514 y ss.

${ }^{87}$ Además de "la expresión del pluralismo político, social y cultural de Andalucía a través de todos los medios de comunicación", como objetivo básico de la Comunidad Autónoma en el ejercicio de sus poderes ( art. 10.3.18ㅡㅡㄹ).

88 Decimos "de manera específica”, por cuanto que otros derechos y principios caben tenerse en cuenta, dado que susceptibles de ser proyectados a los medios de comunicación, en general, como a la actividad televisiva (regional o local), en particular. Así por ejemplo, y además de los objetivos básicos de la Comunidad nuevamente (art. 10 EA, en especial 2, 3.3, 3.4, 3.11, 3.12, 3.15, $3.16,3.17,3.19,3.21,3.22$ y 3.24) y la promoción de los valores democráticos y cívicos (art. 11 EA), los siguientes derechos: igualdad de género (art. 15. EA) y protección contra la violencia de género (art. 16 EA); protección de la familia (art. 17 EA); protección y atención integral de los menores y personas mayores ( respectivamente, arts. 18 y 19 EA); consumidores (art. 27 EA); medio ambiente (art. $28 \mathrm{EA}$ ); participación política (art. $30 \mathrm{EA}$ ); acceso a la cultura y a la tecnología de la información (arts. 33 y $34 \mathrm{EA}$ ); orientación sexual e identidad de género (art. 35); y deberes ( art. 36.1 en particular b, c y f, y 2 EA). Por otra parte, y en cuanto a los principios rectores como instrumentos a través de los cuales lograr los anteriores objetivos y derechos por los poderes públicos andaluces (art. 37.1 EA): la prestación de servicios públicos de calidad ( 1 으); la lucha contra el sexismo, la xenofobia, la homofobia y el belicismo (2); el incentivo del envejecimiento activo y la participación de los mayores en la vida social, educativa y cultural de la comunidad (3); el uso de la lengua de signos española (6\%); la integración de los jóvenes en la vida social ( 8º), y la integración social y cultural de los inmigrantes (9ㅇ); la conciliación de la vida laboral y familiar de hombres y mujeres ( $\left.11^{\circ}\right)$; el fomento de los sectores turístico y agroalimentario (140); el acceso a la sociedad del conocimiento (150); el fortalecimiento de la sociedad civil y el fomento del asociacionismo (16); ; el libre acceso a la cultura y el respeto a la diversidad cultural (17ㅇ); la conservación y puesta en valor del patrimonio cultural, histórico y artístico de Andalucía, y especialmente del flamenco (180); el consumo responsable, solidario, sostenible y de calidad, particular- 
mente en la sociedad del conocimiento, la información y la comunicación, mediante los medios y recursos que la ley establezca ( art. $34 \mathrm{EA}$ ) ${ }^{89}$; y con un carácter más amplio, el Título VIII del Estatuto, relativo a los “medios de comunicación social"90, y especificando en el derecho a la información (art. 207 EA) ${ }^{91}$, la actuación de los medios audiovisuales (art. 208 EA) ${ }^{92}$, la publicidad institucional (art. $209 \mathrm{EA}$ ) ${ }^{93}$, el servicio público de radiotelevisión (art. $210 \mathrm{EA})^{94}$, la regulación de los medios de comunicación públicos (art.

mente en el ámbito alimentario (199); el respeto del medio ambiente, incluyendo el paisaje y los recursos naturales, y la garantía de la calidad del agua y del aire (20); el impulso de las energías renovables, y el ahorro y eficiencia energética (21ㅇ); la convivencia social, cultural y religiosa de todas las personas en Andalucía y el respeto a la diversidad cultural, de creencias y convicciones, fomentando las relaciones interculturales con pleno respeto a los valores y principios constitucionales (23ㅇ) ; y actuaciones en situaciones de emergencia, catástrofe o calamidad pública (25).

89 De interés, María Asunción TORRES LÓ PEZ, “Acceso a las tecnologías de la información y de la comunicación", en AAVV R eformas estatutarias y declaraciones de derechos... cit., pp. 375 y ss.

${ }^{90}$ Con carácter general, sobre el Tít. VIII EA, vid.: Ángel RODRÍGUEZ, “M edios de comunicación social", junto a Francisco BALAGUER CALLEJÓN, Gregorio CÁMARA VILLAR, José Antonio MONTILLA MARTOS y Agustín RUIZ ROBLEDO, en El nuevo Estatuto de Andalucía, Francisco Balaguer Callejón (coord.), Tecnos, Madrid, 2007, pp. 187 y ss.; José María CASTRO PASCU AL, "Medios de comunicación social", en AAVV Comentarios al Estatuto de Autonomía para Andalucía (Ley Orgánica 2/2007... cit., pp. 977 y ss.; y José María SO UVIRÓN MORENILLA, "Los medios de comunicación social", en AAVV Comentarios al Estatuto de Autonomía para Andalucía, Santiago Muñoz Machado y Manuel Rebollo Puig (dirs.), Thomson-Civitas, Pamplona, 2008, pp. 1115 y ss.

91 “1. Los poderes públicos de Andalucía velarán, mediante lo dispuesto en el presente Título, por el respeto a las libertades y derechos reconocidos en el artículo 20 de la Constitución, especialmente los referidos a la libertad de expresión y al derecho a una información independiente, veraz y plural. / 2. Todos los medios de comunicación andaluces, públicos y privados, están sujetos a los valores constitucionales".

92 "Los medios audiovisuales de comunicación, tanto públicos como privados, en cumplimiento de su función social, deben respetar los derechos, libertades y valores constitucionales, especialmente en relación a la protección de la juventud y la infancia, así como velar por el cumplimiento del principio de igualdad de género y la eliminación de todas las formas de discriminación".

93 "Una ley del Parlamento de Andalucía regulará la publicidad institucional en sus diversas formas".

94 "1. El servicio y la gestión de la radiotelevisión de Andalucía tienen carácter público y se prestarán mediante gestión directa. / 2. Sin perjuicio de lo dispuesto en el apartado anterior, se podrán otorgar a entidades y corporaciones públicas y a los particulares concesiones administrativas para la gestión indirecta del servicio público de radiotelevisión. / 3. La Junta de Andalucía gestionará directamente un servicio de radiotelevisión pública". 
211 EA $)^{95}$; la promoción de la cultura andaluza ( art. 212 EA) ${ }^{96}$ y el reconocimiento y uso de la modalidad lingüística andaluza (art. $213 \mathrm{EA})^{97}$, el control democrático de los medios de comunicación gestionados directamente por la Junta y las Corporaciones locales ( art. 214 EA) ${ }^{98}$, la previsión de nuevos canales audiovisuales (art. $215 \mathrm{EA})^{99}$, el espacio radioeléctrico (art. $216 \mathrm{EA}$ ) ${ }^{100}$, y la protección de los derechos en los medios audiovisuales a través del Consejo Audiovisual de Andalucía (art. $217 \mathrm{EA}$ ), viniendo así a institucionalizarlo a nivel estatutario ( $y$ art. $131 \mathrm{EA}$ ) ante su mera previsión legal con carácter previo ( $L$ 1/ 2004, de 17 de diciembre, y D 219/ 2006, de 19 de diciembre, por el que se aprueba el Reglamento Orgánico y de Funcionamiento del Consejo Audiovisual de Andalucía) ${ }^{101}$.

95 “1. Los medios de comunicación de gestión directa por la Junta de Andalucía y las Corporaciones locales orientarán su actividad a la promoción de los valores educativos y culturales andaluces, respetando, en todo caso, los principios de independencia, pluralidad, objetividad, neutralidad informativa y veracidad. / 2 . Se garantiza el derecho de acceso a dichos medios de las asociaciones, organizaciones e instituciones representativas de la diversidad política, social y cultural de Andalucía, respetando el pluralismo de la sociedad".

96 “Los medios de difusión públicos promoverán la cultura andaluza tanto en sus formas tradicionales como en las nuevas creaciones. Fomentarán el desarrollo audiovisual en Andalucía, así como su producción cinematográfica".

97 “Los medios audiovisuales públicos promoverán el reconocimiento y uso de la modalidad lingüística andaluza, en sus diferentes hablas".

98 "1. Corresponde al Parlamento el control de los medios de comunicación social gestionados directamente por la Junta de Andalucía a través de una Comisión Parlamentaria, en los términos que establezca el Reglamento de la Cámara. / 2. La elección del Director o Directora de la Radiotelevisión Pública Andaluza corresponde al Pleno del Parlamento por mayoría cualificada. / 3. I guales funciones corresponden a los Plenos de las Corporaciones respecto de los medios de comunicación públicos locales. / 4. La actividad de control de los medios de comunicación establecida en este artículo tendrá por objeto velar por los principios de independencia, pluralismo y objetividad, así como por una óptima gestión económica y financiera".

99 "La Comunidad Autónoma podrá crear nuevos canales audiovisuales u otros medios de comunicación en el marco del ordenamiento jurídico".

100 “Andalucía será consultada en cualquier decisión que afecte a la planificación o uso de su espacio radioeléctrico o de su sistema de telecomunicaciones".

${ }^{101}$ Art. 217 EA: “Corresponde al Consejo Audiovisual de Andalucía velar por el respeto de los derechos, libertades y valores constitucionales y estatutarios en los medios de comunicación audiovisual, en los términos establecidos en el artículo 131". 
Ahora bien, ¿cómo repercute, efectivamente, este novedoso régimen estatutario de la actividad televisiva local en Andalucía respecto a la normativa autonómica anteriormente comentada? En principio, y en cuanto al marco competencial, dado que la nueva formulación de éste en el Estatuto andaluz viene fundamentalmente a perfilar las competencias autonómicas andaluzas en relación con los medios de comunicación social, en general, y de la actividad televisiva (autonómica y local), en particular, no conlleva realmente un mayor ámbito de competencias al respecto de las que ya se venían asumiendo conforme al anterior marco competencial; otra cosa es que, eso sí, el actual régimen suponga una mayor clarificación del ámbito competencial de la Comunidad Autónoma de Andalucía102. Con todo, es de destacar la previsión estatutaria de que la Junta de Andalucía sea "consultada" por el Estado, con ocasión de la ordenación por éste del espacio radioeléctrico relativo a la Comunidad andaluza (art. $216 \mathrm{EA})^{103}$. Por tanto, y al respecto del marco competencial, no se plantearían particulares cuestiones, a salvo, y como se ha adelantado, de la mayor especificidad de las competencias de la Comunidad Autónoma de Andalucía en cuanto a medios de comunicación social y a la televisión autonómica y local ${ }^{104}$, además de la referida consulta.

Cuestión distinta acontece, ahora, con ocasión del derecho a acceder y a participar activamente en la sociedad de la información y la comunicación que

$102 \mathrm{Al}$ respecto, con carácter general, vid. Francisco BALAGUER CALLEJÓN, "Las últimas reformas estatutarias", junto a Gregorio CÁMARA VILLAR, Juan Fernando LÓ PEZ AGUILAR, María Luisa BALAGUER CALLEJÓN y José Antonio MONTILLA MARTOS, en M anual de Derecho Constitucional (I), Francisco Balaguer Callejón (coord.), 3ạ ed, Tecnos, Madrid, 2008, pp. 374 y ss.

103 Cfr.: Ángel RODRÍGUEZ, “Medios de comunicación social... cit., pp. 189 y 190; y Emilio GUICHOT REINA, "Competencias sobre medios de comunicación social y publicidad (Comentario a los arts. 69 y 70)", en AAVV Comentarios al Estatuto deAutonomía para Andalucía... cit., p. 681. Al respecto de dicha consulta, estimamos adecuada su articulación a través de la Comisión Bilateral de Cooperación Junta de Andalucía-Estado, dado que cauce general y permanente de relación entre ambos (art. 220 EA); sobre dicha Comisión, vid.: José Antonio MONTILLA MARTOS, "Relaciones institucionales de la Comunidad Autónoma con el Estado y con otras Comunidades Autónomas", en AAVV EI nuevo Estatuto de Andalucía... cit., pp. 195 y ss.; y Mariano LÓ PEZ BENíTEZ, "Las relaciones institucionales de la Comunidad Autónoma con el Estado", asimismo en AAVV Comentarios al Estatuto de Autonomía para Andalucía... cit., pp. 1159 y ss.

104 En tal sentido, a nivel general, José Antonio MONTILLA MARTOS, pero ahora "Competencias de la Comunidad Autónoma. Materias Competenciales", asimismo en AAVV EI nuevo Estatuto de Andalucía... cit., pp. 65 y ss.; y de manera más concreta, en relación al art. 69 EA, José María SOUVIRÓN MORENILLA, “Los medios de comunicación social... cit., pp. 1123 a 1128. 
el Estatuto andaluz viene a reconocer en su artículo 34, como en relación a la propia regulación que de los medios de comunicación social éste ofrece en su Título VIII (según lo apuntado más arriba). Y es que, aunque buena parte de tal contenido sustantivo estatutario ya se encontraba en el ordenamiento jurídico andaluz, su consagración y racionalización a nivel estatutario supone, además de una cierta definición política del ejercicio de las competencias relativas a los medios de comunicación social y la televisión por los poderes públicos andaluces, un límite y un impulso de la acción jurídica y política de los mismos al respecto105; por tanto, no es una mera institucionalización estatutaria de contenidos que estaban desperdigados a nivel legal y reglamentario en Andalucía en torno a los medios de comunicación social y la televisión autonómica y local, sino una auténtica sistematización de un modelo, aunque abierto y plural, del sector mediático-social y televisivo en Andalucía.

A tales efectos, entonces, cabe apreciar, y todavía desde una perspectiva formal relativa al derecho a participar en la sociedad de la información y la comunicación, su reconducción jurídica a los "medios y recursos que la ley establezca" (art. 34, in fine, EA), lo que supone una reserva de ley al respecto (y con carácter general, art. $38 \mathrm{EA})^{106}$, frente a la regulación meramente reglamentaria con la que hasta ahora se ha normado desde Andalucía la televisión local (DD 414/ 2000, 365/ 2003, y 1/ 2006). O tra cosa es, desde una perspectiva material sobre tal derecho, cómo quepa articularse, por cuanto que dicha participación cabe llevarse a cabo tanto en relación a medios públicos televisivos, como directamente mediante la gestión de éstos por los propios particu-

105 Cfr.: Gregorio CÁMARA VILLAR, "Derechos, deberes y principios rectores", en AAVV EI nuevo Estatuto deAndalucía... cit., pp. 23 y ss. (en especial, pp. 28 y 29); y Juan Francisco SÁNCHEZ BARRILAO, "La garantía jurisdiccional de los derechos estatutarios", en AAVV Reformas estatutarias y declaraciones de derechos... cit., pp. 117 y 118.

106 “La prohibición de discriminación del artículo 14 y los derechos reconocidos en el CapítuIo II vinculan a todos los poderes públicos andaluces y, dependiendo de la naturaleza de cada derecho, a los particulares, debiendo ser interpretados en el sentido más favorable a su plena efectividad. El Parlamento aprobará las correspondientes leyes de desarrollo, que respetarán, en todo caso, el contenido de los mismos establecido por el Estatuto, y determinarán las prestaciones y servicios vinculados, en su caso, al ejercicio de estos derechos". Ya, sobre el alcance de tal reserva legal, en general, vid. María HOLGADO GONZÁLEZ, en AAVV La reforma del Estatuto de Autonomía para Andalu cía: L os derechos sociales de los andaluces. Deberes y políticas públicas (Pareceres), Manuel José Terol Becerra (dir.), Instituto Andaluz de Administración Pública, Sevilla, 2007, p. 91; otra vez Gregorio CÁMARA VILLAR, op. cit., p. 36; y Manuel REBOLLO PUIG, "EI Derecho propio de Andalucía y sus fuentes", en AAVV Comentarios al Estatu to de Autonomía para Andalucía... cit., pp. 230 a 232. 
lares ${ }^{107}$; y es que, y a diferencia del derecho de acceso a los medios de comunicación recogido en el artículo 20.3 de la Constitución (según se ha señalado), el vigente artículo 34 del Estatuto andaluz no limita tal derecho a los grupos sociales, ni a los medios televisivos públicos. En tal sentido, el artículo 210.2 del Estatuto andaluz, de un lado, tras declarar el carácter público del servicio y la gestión de la radiotelevisión de Andalucía, prevé, expresamente, la posibilidad de su gestión indirecta por "entidades y corporaciones públicas", como por "particulares"; mientras que, de otra, el 211.2 garantiza, ahora sí en estrecha relación con el artículo 20.3 de la Constitución, "el derecho de acceso a dichos medios [ públicos] de las asociaciones, organizaciones e instituciones representativas de la diversidad política, social y cultural de Andalucía, respetando el pluralismo de la sociedad"108; y todo ello, a su vez, garantizándose además el control democrático de los medios de comunicación gestionados directamente por las Corporaciones locales (nuevamente, art. 214 EA).

Por último, y a nivel de principios reguladores de la actividad televisiva local en Andalucía, destaca la plena compatibilidad del régimen previsto en el Decreto 1/ 2006 (arts. 6 y 14 y ss.), con los genéricamente definidos en el Título VIII del Estatuto (los referidos arts. 208, 211.1, 212, 213 y 217).

\section{IV.D.- EL CESE EFECTIVO EN ANDALUCÍA DE EMISIONESTELEVISIVAS LOCALES EN ANALÓGICO}

Junto a la previsión del tres de abril de 2010 como fecha tope de retransmisión de emisiones televisivas en analógico (según se apuntó al comienzo de estas páginas), de acuerdo a la comentada disposición transitoria primera, apartado cuarto, de la Ley 41/ 1995 las emisoras de televisión local que no obtengan la respectiva concesión administrativa deben de dejar "de emitir en un plazo de seis meses contado desde la resolución del concurso o, en su defec-

107 Acerca de la doble participación de los ciudadanos en los medios televisivos, ya en los públicos mediante la reserva de específicos espacios, como a través de medios directamente en manos de aquéllos, en Derecho comparado, vid. José Carlos LAGUNA DE PAZ, Régimen jurídico de la televisión privada... cit., pp. 35 y ss.

${ }^{108}$ No obstante, el alcance del reconocimiento del derecho de acceso previsto en el art. 211.2 EA resulta superior al art. 20.3 CE, por cuanto que abierto no sólo a "grupos sociales y políticos significativos" (art. 20.3 CE), sino a "asociaciones, organizaciones e instituciones representativas de la diversidad política, social y cultural de Andalucía" (art. 211.2 EA). Al respecto, cfr. José María SOUVIRÓN MORENILLA, “Los medios de comunicación social... cit., pp. 1142 y 1143. 
to, en un plazo de seis meses desde que se agote el plazo para resolver la adjudicación a la que se refiere la disposición transitoria segunda"; y ello, se recuerda, sin que "suponga derecho a indemnización a los efectos del artículo 139.3 de la Ley 30/ 1992". Y asimismo, conforme a la disposición transitoria única del Decreto 1/ 2006 de la Junta de Andalucía, tales emisoras deberán dejar "de emitir en un plazo de 6 meses a contar desde la resolución del concurso". En este sentido, mediante Acuerdo de 29 de julio de 2008 el Consejo de Gobierno vendría a resolver el concurso para el otorgamiento de concesiones para la explotación del servicio público de televisión digital terrestre de ámbito local en Andalucía para su gestión por particulares, convocado por anterior Acuerdo del mismo de 18 de abril de 2006, y conforme al cual se han otorgado 163 licencias distribuidas entre las 57 demarcaciones correspondientes a las ocho provincias andaluzas (de un total de 186 que salieron a concurso público) ${ }^{109}$. Por tanto, cualquier televisión local que venga emitiendo en analógico y no haya obtenido la referida concesión administrativa para emitir en digital ha de dejar de emitir efectivamente, de manera que la Comunidad podrá, consecuentemente, iniciar el correspondiente procedimiento sancionador a tal fin (nuevamente, art. 45 D 1/ 2006).

No obstante, y según se ha comentado más arriba, la Junta de Andalucía (en particular, al amparo del D 365/2003) ha venido tolerando la emisión por aquellas televisiones que no se hallaban incluidas en el régimen transitorio de la Ley 41/ 1995 (disp, adic. 1a.1 y disp. trans.) con lo que, y a pesar de la contundencia del régimen transitorio hoy fenecido, y del claro y terminante deber de las televisiones locales analógicas que no han obtenido la correspondiente concesión de dejar de emitir, cabe plantearse cuál sea la decisión de la Junta a seguir. Desde luego que ésta puede obligarlas a que dejen de emitir, y ello especialmente en relación al momento último en que se establezca el apagón analógico en el referido ámbito territorial en que vengan operando; pero también cabe que la Junta, simplemente, espere a que el paso tecnológico de la televisión analógica a la digital termine por agotar la emisión en analógico ante la falta de receptores televisivos en tal modalidad. Desde luego esta opción no resulta estrictamente legítima de acuerdo a la normativa vigente, pero sí que se aviene con la actitud que la Junta ha mantenido hasta ahora, además de ser conforme al referido principio jurídico de confianza legítima.

${ }^{109}$ L as 23 licencias no adjudicadas quedaron desiertas por falta de licitadores. De otro lado, también, está el caso del no otorgamiento de concesiones a televisiones locales consideradas históricas, a favor de grupos foráneos, como por ejemplo ha acontecido con "Televisión Carmona" (y así, declaración institucional del Ayuntamiento de Carmona, de 17 de junio de 2009, a favor de la misma). 
Así, y más allá del referido apagón analógico ( y de la prohibición de emisión en dicha modalidad técnica), es dable operar con la idea de seguir tolerando la televisión local analógica hasta tanto se deje de emitir simplemente por falta de su efectiva recepción; tolerancia, eso sí, condicionada al respeto de los principios que rigen la actividad televisiva local, y siempre y cuando no entorpezca o limite el espacio público radioeléctrico según sea definido y gestionado en cada momento. Si el Derecho está llamado ordenar jurídicamente la realidad, y en algunos casos (como en éste) a colaborar en su misma conformación fáctica (y tecnológica!) , no es menos cierto que no tiene sentido insistir en la prohibición de una actividad que está llamada a desaparecer por el mismo devenir de los hechos y del desarrollo tecnológico y del mercado televisivo. Y es que no creemos que el apagón analógico haya de entenderse como una mera prohibición jurídica de una modalidad tecnológica de la actividad televisiva (lo cual, por sí, sería difícilmente justificable), sino como un proceso de racionalización jurídica del espacio radioeléctrico existente a fin de procurar su máximo rendimiento, y por tanto que no sea oportuno incitar a la firme y efectiva prohibición de la televisión local analógica en abstracto (por lo demás, en muchos casos circunscrita a pequeños radios de acción) salvo que dicha actividad perjudique potencial o de factum tal espacio de manera concreta; y todo ello, en especial, a la vista de cómo con tal actividad caben desarrollarse y ejercerse instrumentalmente libertades públicas y derechos fundamentales.

Con todo, ciertamente, la referida disposición adicional decimoctava de la Ley 56/ 2007, relativa a la "televisión de proximidad sin ánimo de lucro", abre una nueva espita transitoria para aquellas televisiones locales en Andalucía que vengan emitiendo antes del uno de enero de 1995 y se consideren integradas en el régimen previsto por dicha disposición; y ello, en tanto que sea desarrollado reglamentariamente por el Estado y ulteriormente por la Comunidad Autónoma andaluza, y ésta finalmente haya resuelto las oportunas concesiones al respecto.

\section{EPÍLOGO: EL PROYECTO DE LEY GENERAL DE LA COMUNI- CACIÓN AUDIOVISUAL}

\section{V.A.- APROXIMACIÓN CRÍTICA AL NUEVO RÉGIMEN LEGAL DE LA TE- LEVISIÓN QUE SUPONE EL PROYECTO DE LEY AUDIVISUAL.}

Más allá de lo indicado hasta el momento, el Proyecto de Ley General de la Comunicación Audiovisual (PLGCA) que actualmente se tramita en las Cor- 
tes Generales ${ }^{110}$ vendrá (en caso de prosperar finalmente, como así se prevé) a alterar radicalmente el anterior marco legal de la televisión en España, al pasarse a un modelo mixto y concurrente de servicio público televisivo (esencial) en manos directamente de los poderes públicos, junto a un servicio televisivo (de interés general) realmente privado (arts. 2, 22 y 40); y al respecto del cual, sin previsión de un número máximo de canales, por cuanto que sujeto a la disponibilidad del espacio radioeléctrico conforme al desarrollo tecnológico (art. 27), aunque, eso sí, fijándose un número mínimo de prestadores a nivel estatal a fin de garantizar un pluralismo mínimo audiovisual (art. 36.5.c). Pero pasemos, aun someramente, a presentar los aspectos más novedosos y generales del PLGCA, para seguidamente ofrecer alguna que otra apreciación crítica al nuevo diseño legal que de la televisión se plantea.

Con el objeto expreso de ofrecer una nueva ordenación del mercado audiovisual (alcanzando ahora el de la información, más el del mercado del ocio y el de la venta audiovisual), a la par que desarrollar el Derecho europeo al respecto (Directiva 2007/ 65/ CE de Servicios de Comunicación Audiovisual del Parlamento Europeo y del Consejo de 11 de diciembre del 2007), el PLGCA plantea un ambicioso nuevo marco regulatorio de la comunicación audiovisual estructurado en seis Títulos, y destacando un amplio segundo (normativa básica para la comunicación audiovisual) que contiene: de un lado, un novedoso catálogo de derechos del público (Cap. I), con los que parecería desarrollarse la vertiente receptiva de la actividad televisiva111; y de otro, los derechos de los prestadores (privados) del servicio de comunicación audiovisual (Cap. II), distinguiendo en relación a la libertad en la dirección editorial, el derecho de acceso a los servicios de comunicación audiovisual y el derecho a la autorregulación (Sec. 1aㅡ), el derecho a realizar comunicaciones comercia-

110 Del que ya hemos advertido en las notas 2 y 3 . A los efectos de estas páginas, se cita el texto presentado por la ponencia nombrada en el seno de la Comisión Constitucional del Congreso de los Diputados, y debatido y aprobado (con competencia legislativa plena) el 7 de enero de 2010 ( si bien se acordaron ciertas enmiendas en tal sesión). Al momento de redacción de estas últimas páginas, el texto se encuentra ya remitido al Senado (aunque aún no ha sido publicado oficialmente). Para una primera aproximación al texto, vid. José María VIDAL BELTRÁN, "EI nuevo marco jurídico del audiovisual en España", El Cronista del Estado Social y Democrático de Derecho, núm. 10, 2010, pp. 30 y ss.

111 Y recogiendo los siguientes derechos: recibir una comunicación audiovisual plural (art. 4); diversidad cultural y lingüística (art. 5); una comunicación audiovisual transparente (art. 6); derechos del menor (art. 7) y de las personas con discapacidad (art. 8); y participación en el control de los contenidos audiovisuales ( art. 9). 
les ( Sec. 2a ${ }^{112}$, y a la contratación en exclusiva de la emisión por televisión de contenidos audiovisuales ( $\mathrm{Sec}$. 3a). También destaca un amplio, asimismo, Título tercero sobre normas básicas para la regulación y coordinación del Mercado de Comunicación Audiovisual, y especificando a su vez el régimen jurídico básico de la prestación de servicios de comunicación audiovisual en un mercado competitivo, transparente y plural (Cap. I) ${ }^{113}$, conforme al cual: se definen los servicios de comunicación audiovisual como servicios de interés general y al respecto de lo cual se establece su régimen jurídico, resaltando su desarrollo conforme a la libertad de empresa y la libre competencia dentro de un mercado transparente y plural (si bien, también, "desde el respeto y la protección de los principios y valores constitucionales y del derecho a comunicar y recibir una información objetiva y veraz"), y requiriendo mera licencia previa cuando dichos servicios se presten mediante ondas hertzianas terrestres, previo concurso por autoridad audiovisual competente (art. 22) ${ }^{114}$; se establece el régimen de explotación de las redes de comunicaciones electrónicas y servicio de comunicación audiovisual, destacando cómo los prestadores de tales servicios han de garantizar el derecho de acceso a los prestadores del servicio de comunicación audiovisual y productores independientes, así como "la posibilidad técnica de transmitir imagen y sonido en condiciones que permitan una interactividad efectiva" (art. 31); la previsión de servicios, como gran novedad, de "comunicación audiovisual comunitarios sin ánimo de lucro" (art. 32) ${ }^{115}$, y de registros de prestadores del servicio de comunicación audio-

112 E integrando los derechos a: crear canales de comunicación comercial y programas o anuncios de autopromoción (art. 13); emitir mensajes publicitarios (art. 14) y de venta (art. 15); patrocinio (art. 16); y emplazamiento de productos (art. 17). Además, se hace referencia a las comunicaciones comerciales prohibidas en cualquiera de sus formas (art. 18).

${ }^{113}$ En cuanto al Cap. II, se regula la libertad de recepción de los servicios de comunicación audiovisual prestados desde fuera de España, y ello en relación a los prestados dentro del Espacio Económico Europeo (art. 38), y especialmente a los dirigidos, total o principalmente, al territorio español (art. 39).

${ }^{114}$ En otro caso, bastará comunicación previa, de acuerdo al art. 23. Por otra parte, en cuanto a las licencias audiovisuales, se establece su régimen jurídico (art. 24); los requisitos para ser titular de las mismas, y ello tanto en relación a personas físicas como jurídicas (art. 25); limitaciones por razones de orden público audiovisual (art. 26); la previsión de los concursos para la concesión de las referidas licencias (art. 27); duración -ampliada a 15 años- y renovación automáticas de las mismas (art. 28), así como negocios jurídicos sobre éstas, incluyendo su transmisión y arrendamiento (art. 29); y la extinción de las licencias audiovisuales (art. 30).

115 “1. Las entidades privadas que tengan la consideración legal de entidades sin ánimo de lucro podrán prestar servicios de comunicación audiovisual que ofrezcan contenidos dirigidos a 
visual (art. 33) ; se distinguen y especifican nuevas formas de comunicación audiovisual, como la televisión en movilidad y en alta definición (arts. 34 y 35, respectivamente); y el establecimiento de un marco de reglas para el mantenimiento de un mercado audiovisual competitivo, transparente y plural, conforme al cual se permite que "las personas físicas y jurídicas pueden ser titulares simultáneamente de participaciones sociales o derechos de voto en diferentes prestadores del servicio de comunicación audiovisual televisiva" (art. 36.1) , si bien no podrán "adquirir una participación significativa en más de un prestador del servicio de comunicación audiovisual televisiva de ámbito estatal, cuando la audiencia media del conjunto de los canales de los prestadores de ámbito estatal considerados supere el $27 \%$ de la audiencia" (art. 36.2) ${ }^{116}$. En cuanto a los otros Títulos, el primero (disposiciones generales) se refiere al objeto (art. 1), definiciones (art. 2) y ámbito de aplicación (art. 3), el Títu-

atender las necesidades sociales, culturales y de comunicación específicas de comunidades y grupos sociales, así como a fomentar la participación ciudadana, la vertebración del tejido asociativo y el desarrollo local y comunitario. En todo caso, dichos contenidos se emitirán en abierto y sin ningún tipo de comunicación audiovisual comercial. / 2. La Administración General del Estado debe garantizar en todo caso la disponibilidad del dominio público radioeléctrico necesario para la prestación de estos servicios. / 3. La prestación de este tipo de servicios requiere licencia previa. En dicho título se establecerán las condiciones que aseguren su naturaleza sin finalidad comercial, pudiendo establecerse el uso compartido de un mismo canal así como las condiciones de dicho uso [... . . / 4. Las entidades prestadoras de estos servicios deberán justificar la procedencia de sus fondos, así como el desglose de gastos e ingresos, si los hubiere. [... ]. / Sus gastos de explotación anuales no podrán ser superiores a 100.000 euros en el caso de la televisión [... ]. / 5. Las entidades titulares de los servicios de comunicación audiovisual sin ánimo de lucro deberán acreditar el pago de $[\ldots] "$.

116 Sigue diciendo el art. 36 PLGCA: “3. La superación del 27\% de la audiencia total con posterioridad a la adquisición de una nueva participación significativa no tendrá ningún efecto sobre el titular de la misma. / 4. Las participaciones sociales o los derechos de voto de personas físicas o jurídicas nacionales de países que no sean miembros del Espacio Económico Europeo [... ]. / 5. Ninguna persona física o jurídica podrá adquirir una participación significativa o derechos de voto en más de un prestador del servicio de comunicación audiovisual televisiva: / a) Cuando los prestadores del servicio de comunicación audiovisual de ámbito estatal acumulen derechos de uso sobre el dominio público radioeléctrico superiores, en su conjunto, a la capacidad técnica correspondiente a dos canales múltiplex. / b) Cuando los prestadores del servicio de comunicación audiovisual de ámbito autonómico acumulen derechos de uso sobre el dominio público radioeléctrico superiores, en su conjunto, a la capacidad técnica correspondiente a un canal múltiplex. ( c) Ninguna persona física o jurídica titular o partícipe en el capital social de un prestador del servicio de comunicación audiovisual televisiva de ámbito estatal podrá adquirir una participación significativa o derechos de voto en el capital de otro prestador del mismo servicio, cuando ello suponga impedir la existencia de, al menos, tres prestadores distintos del servicio de comunicación audiovisual televisiva en el ámbito estatal, asegurándose el respeto al pluralismo informativo". 
lo cuarto se dedica a los prestadores públicos del servicio de Comunicación Audiovisual [definición del servicio público audiovisual (art. 40); función de dicho servicio público y su control (art. 41); límites para los prestadores de servicio público de titularidad pública (art. 42) ; y financiación de tales prestadores (art. 43) ], el quinto al Consejo Estatal de Medios Audiovisuales [naturaleza, fines y régimen jurídico (arts. 44 a 46); funciones, potestades y facultades (arts. 47 a 48); organización y garantías de independencia (arts. 49 a 52); control parlamentario (art. 53) ; y agotamiento de la vía administrativa y control jurisdiccional (art. 54) ], y el Título sexto al régimen sancionador básico. Además, el PLGCA prevé una disposición adicional, once transitorias (destacando la segunda, relativa a los derechos reconocidos y títulos otorgados antes de la entrada en vigor del PLGCA), una amplísima derogatoria (que viene a derogar casi en su integridad el marco legal de la televisión referido en las anteriores páginas) ${ }^{117}$, y cinco finales, sobresaliendo la segunda, relativa a la in-

117 “[... ] en concreto, quedan expresamente derogadas: / 1. La Ley 4/ 1980, de 10 de enero, del Estatuto de la Radio y la Televisión. / 2. La Ley 46/ 1983, de 26 de diciembre, del Tercer Canal de Televisión. / 3. La Ley 31/ 1987, de 18 de diciembre, de Ordenación de las Telecomunicaciones. / 4. La Ley 10/ 1988, de 3 de mayo, de Televisión Privada. / 5. La Ley 11/ 1991, de 8 de abril, de Organización y control de las emisoras municipales de radio. / 6. La Ley 25/ 1994, de 12 de julio, por la que se incorpora al ordenamiento jurídico español la Directiva 89/ 552/ CEE, sobre la coordinación de disposiciones legales, reglamentarias y administrativas de los Estados miembros, relativas al ejercicio de actividades de radiodifusión televisiva. / 7. La Ley 37/ 1995, de 12 de diciembre, de Telecomunicaciones por Satélite, en lo referido a los servicios de comunicación audiovisual por satélite. / 8. La Ley 41/ 1995, de 22 de diciembre, de Televisión Local por Ondas Terrestres. / 9. La Ley 21/ 1997, de 3 de julio, reguladora de las Emisiones y Retransmisiones de Competiciones y Acontecimientos Deportivos. / 10. La disposición adicional cuadragésimo cuarta de la Ley 66/ 1997, de 30 de diciembre, de Medidas Fiscales, Administrativas y del Orden Social. / 11. La disposición adicional cuadragésimo cuarta de la Ley 50/ 1998, de 30 de diciembre, de Medidas Fiscales, Administrativas y del Orden Social. / 12. La disposición adicional segunda de la Ley 15/ 2001, de 9 de julio, de fomento y promoción de la cinematografía y el sector audiovisual. / 13. Las disposiciones adicionales décima y transitorias sexta y décima de la Ley 32/ 2003, de 3 de noviembre, General de Telecomunicaciones. / 14. La disposición adicional trigésima de la Ley 62/ 2003, de 30 de diciembre, de Medidas Fiscales, Administrativas y de Orden Social. / 15. La Ley 10/ 2005, de 14 de junio, de Medidas U rgentes para el Impulso de la Televisión Digital Terrestre, de Liberalización de la Televisión por Cable y de Fomento del Pluralismo, salvo el artículo 5 que modifica el Real Decreto-ley 1/ 1998, de 27 de febrero, sobre infraestructuras comunes en los edificios para el acceso a los servicios de telecomunicación, y salvo la disposición adicional segunda, relativa a la garantía de accesibilidad para personas con discapacidad y la disposición adicional séptima, relativa a la cobertura por satélite del servicio de televisión digital terrestre de ámbito estatal. / 16. Ley $7 / 2009$, de 3 de julio, de medidas urgentes en materia de Telecomunicaciones. / 17. Real Decreto-Ley 11/ 2009, de 13 de agosto, por el que se regula para las concesiones de ámbito estatal, la prestación del servicio de televisión digital terrestre de pago mediante acceso condicional". 
corporación del Derecho de la Unión Europea, y la tercera, sobre los títulos competenciales invocados por el Estado al respecto del PLGCA, conforme a la cual sus preceptos se dictan "al amparo de la competencia del Estado para dictar legislación básica del régimen de [..] televisión" (art. 149.1.27. CE) ${ }^{118}$.

Al margen de la necesidad de una regulación general, coherente y actualizada del marco legal de la actividad televisiva, según el propio PLGCA en su exposición de motivos, lo cierto es que el proyecto presenta no pocas cuestiones abiertas a consideraciones críticas, como son ( y aún muy someramente): primero, el que siendo el PLGCA una regulación pretendidamente general y unitaria de la actividad televisiva, no se está tramitando (y aprobando) como ley orgánica (art. $81 \mathrm{CE}$ ), frente a la referida Sentencia del Tribunal Constitucional 127/ 1994, conforme a la cual era dable el carácter de ley ordinaria de la Ley 10/ 1988 de la Televisión Privada, entre otros motivos, al no ser "una regulación directa, general y global" (FJ núm. 3.b) ${ }^{119}$; segundo, y en sintonía con la condición de mera ley ordinaria del PLGCA ( sin embargo), la regulación de un régimen televisivo fundamentalmente basado en la televisión privada (art. $38 \mathrm{CE}$ ), y más allá por tanto de la libertad de antena (art. 20.1 CE), salvo el referido supuesto de los servicios de comunicación audiovisual comunitarios sin ánimo de lucro (art. 32); tercero, y asimismo, la configuración de los derechos del público esencialmente como límites a la actividad televisiva privada, en vez de auténtica manifestación de un genuino derecho fundamental de recepción televisiva ${ }^{120}$; cuarto, la reducción del carácter esencial de la televisión sólo en relación a la actividad televisiva gestionada directamente por los poderes públicos, así como por los servicios de comunicación comunitarios (nuevamente, art. 32), quedando la privada centrada en el ocio y en la

118 Continúa la disp. final tercera: “[ ... ] salvo los artículos 5.3, párrafo sexto, 11 y 31 que se dictan al amparo de la competencia estatal exclusiva en materia de telecomunicaciones, prevista por el artículo 149.1.21. a de la Constitución. Las previsiones de esta Ley son de aplicación a todas las Comunidades Autónomas respetando, en todo caso las competencias exclusivas y compartidas en materia de medios de comunicación y de autoorganización que les atribuyen los respectivos Estatutos de Autonomía".

${ }^{119} \mathrm{AI}$ respecto, Juan Francisco SÁNCHEZ BARRILAO, "EI derecho fundamental a la actividad televisiva (II) ... cit., pp. 596 y 597.

${ }^{120}$ Con todo, particular interés e importancia tienen los derechos: a recibir una comunicación audiovisual "a través de una pluralidad de medios tanto públicos, comerciales como comunitarios [... ]" (art. 4.1); y a una comunicación audiovisual transparente, en relación al derecho a conocer la identidad del prestador del servicio de comunicación audiovisual, el cual integra información relativa a "las empresas que formen parte de su grupo y el accionariado" (art. 6.1). 
venta; quinto, la sujeción del pluralismo al mercado, de manera que se permite una importante concentración de medios [ a salvo de una garantía de tres prestadores a nivel estatal, con lo que vendría reducirse el número actual (nuevamente, art. 36) ], a la par que se fomenta la mera multiplicación de canales ( más pluralismo de mercado, pero menos pluralismo informativo); sexto, la falta de un régimen transitorio capaz de cubrir eficaz y eficientemente el notabilísimo cambio que del régimen jurídico se prevé; y por último, y en general, un cambio excesivamente rupturista en relación al anterior modelo, en vez de profundizar en la evolución que de tiempo venía dándose a favor de una mayor liberalización de la actividad televisiva, a la par que incidiendo más en los derechos del público en tanto que ciudadanos (en vez de meros usuarios y/ o consumidores).

\section{B.- LA TELEVISIÓN LOCAL EN LA LEY GENERAL DE LA COMUNICA- CIÓN AUDIVISUAL}

En cuanto al específico régimen jurídico de la televisión local previsto por el PLGCA, éste nos dice formalmente muy poco al respecto. De un lado, la expresa derogación de la Ley 41/ 1995 (disp. derogatoria, apartado 80), y de otro: la concreta referencia a la televisión local en relación al ámbito de las licencias de prestadores audiovisuales (art. 22.3) 121; la integración de lo local dentro del marco de acción de los servicios de comunicación audiovisual comunitarios sin ánimo de lucro (otra vez, art. 32.1); la consideración de las Entidades Locales como prestadoras del servicio público de comunicación audiovisual ( art. 40.2) ${ }^{122}$, correspondiendo a sus órganos de gobierno "el control de la gestión y del cumplimiento de la función de servicio público" (art. 41.2) y la determinación normativa del "sistema de financiación de su servicio público de comunicación audiovisual" (art. 43.1); y la transformación en licencias de la actuales concesiones administrativas de televisión local (disp. transitoria $\left.2^{a} .1\right)^{123}$. Por tanto, se habrá de estar a la regulación que de la televisión

121 “[ ... ] Para la prestación del servicio de comunicación televisiva las licencias de ámbito local podrán corresponder a uno o varios municipios limítrofes y, en su caso, a un ámbito insular completo. / El otorgamiento de una licencia de televisión de ámbito local no faculta para la emisión en cadena con otras entidades autorizadas, durante más del $25 \%$ del tiempo total semanal, aunque sea en horario diferente. En ningún caso este porcentaje puede concentrarse en el horario de 21 a 24 horas".

122 “[... ] las Entidades Locales podrán acordar la prestación del servicio público de comunicación audiovisual con objeto de emitir en abierto canales generalistas o temáticos".

123 “1. Las concesiones para la gestión indirecta del servicio público de radio o televisión por ondas hertzianas terrestres de ámbito estatal, autonómico o local se deben transformar en licen- 
local prevean las Comunidades Autónomas al respecto (en el caso de Andalucía, conforme al régimen anteriormente señalado y aún a nivel reglamentario), a salvo de la condición básica del casi entero PLGCA y por tanto su traslación y desarrollo al ámbito local por éstas, en lo que sea posible ${ }^{124}$; mas ello, sin perjuicio del mantenimiento, y sin embargo, de la vigencia de la disposición adicional decimoctava de la Ley 56/2007, sobre la televisión de proximidad sin ánimo de lucro, por cuanto que no se prevé su derogación por el PLGCA (disp. derogatoria), así como su estrecha relación con los referidos prestadores comunitarios (de nuevo, art. 32.1).

En tal contexto, la derogación de la Ley 41/ 1995 (y la previsible entrada en vigor de la LGCA al tiempo del definitivo apagón analógico), junto al déficit normativo transitorio del PLGCA (señalado en el anterior apartado), no ayuda precisamente a fomentar un mayor grado de seguridad jurídica con relación al cese (y cierre) de emisiones televisivas en analógico a nivel local; al contrario, se fomenta la inseguridad respecto a un marco ya de por sí mudable e incierto (según se ha mostrado), sin perjuicio del mantenimiento implícito de las televisiones de proximidad.

cias para la prestación del servicio de comunicación audiovisual. / La vigencia de las nuevas licencias será de quince años a contar desde la fecha de transformación de las concesiones".

124 Lo cual, a su vez, es un problema al presente, dado la sujeción de la normativa autonómica al vigente régimen de la televisión local, y la profunda transformación que al respecto supone el PLGCA. 